\title{
Dignity and Conflicts of Constitutional Values: The Case of Free Speech and Equal Protection
}

\author{
R. GEORGE WRIGHT*
}

\section{TABLE OF CONTENTS}

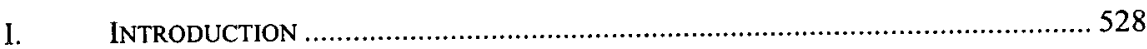

II. THE Dignity OF THE PERSON: SOME CONSIDERATIONS fRom

THE GeNERAL CASE LAW.

III. SOME ClASSICAL ACCOUNTS OF THE GROUNDS AND

MEANINGS OF DIGNITY

IV. SOME CONTEMPORARY TREATMENTS OF THE IDEA OF DIGNITY ........................... 548

V. DigNITY AND THE MEDIATION OF FREE SPEECH AND EQUAL

PROTECTION

A. Some General Relationships Between Freedom and Equality .................. 559

B. Freedom of Speech, Hate Speech, the Equal Protection of the Laws, and the Dignity of the Person

C. Speech, Equality, and the Mediating Value of Dignity in the Public School Confederate Flag Cases.

VI. CONCLUSION

* Michael D. McCormick Professor, Indiana University School of LawIndianapolis. The Author extends his thanks to Rachel Scherer for her remarkable research and editing assistance. 


\section{INTRODUCTION}

Dignity can mean many things. ${ }^{\prime} \quad$ In no sense is dignity itself a recognized constitutional right. But that hardly shows that dignity is constitutionally trivial. Dignity may help explain why we recognize constitutional rights in the first place. ${ }^{2}$ It may also help explain the value, scope, and limits of constitutional rights. ${ }^{3}$ Of more immediate interest, dignity may help to fairly adjudicate between constitutional claims in conflict. ${ }^{4}$

This Article focuses on dignity in a fundamental sense: ${ }^{5}$ as a value that can fairly adjudicate between and make commensurate the often conflicting constitutional values of free speech and equal protection. ${ }^{6}$ Dignity does not invariably push conflicts between free speech and equal protection toward the same resolution in every case. ${ }^{7}$ Dignity in the crucial sense can support or oppose the priority of either free speech or equal protection claims, depending upon the circumstances. ${ }^{8}$

This use of dignity should not be surprising. After all, dignity in a sufficiently deep sense is hardly foreign to our best explanations of the constitutional status of both free speech and equal protection. ${ }^{9}$ Dignity can thus provide something of a shared framework for assessing

1. 4 THE OXFORd ENGLISH DiCTIONARY 656-57 (J.A. Simpson \& E.S.C. Weiner eds., $2 \mathrm{~d}$ ed. 1989) lists eleven distinguishable meanings of the term dignity, though several are related and others are either obsolete or of minimal interest. The definition of greatest interest for the purposes of this Article is the first: "The quality of being worthy or honorable; worthiness, worth, nobleness, excellence." Even this definition, though, to the extent that it focuses on excellence, may tend to set up a conflict between dignity and equality. $I d$. at 656.

2. See Alan Gewirth, Human Dignity as the Basis of Rights, in THE CONSTITUTION OF Rights: Human DigniTY AND AMERICAN VAlues 10 (Michael J. Meyer \& William A. Parent eds., 1992).

3. See infra Part II.

4. See infra Part V.

5. See infra Parts III-IV.

6. See infra Part V.

7. See infra Part V.

8. See infra Part V.

9. See infra Part V.A. Ronald Dworkin offers a crucial, noninstrumental justification of free speech: "[W]e retain our dignity, as individuals, only by insisting that no one ... has the right to withhold an[other's] opinion from us on the ground that we are not fit to hear and consider it." RONALD DWORKIN, FREEDOM'S LAW 200 (1996). In contrast, Catharine MacKinnon argues that "racist propaganda [causes] harms of social inequality [in the form of] deprivation of human dignity," among other harms, when protected as free speech. Catharine A. MacKinnon, Speech, Equality, and Harm, in ThE Price We PAY 301 (Laura J. Lederer \& Richard Delgado eds., 1995). 
conflicting constitutional claims involving free speech and equal protection.

Adding to the plausibility of this approach, dignity considerations do not suggest that either free speech or equal protection concerns should invariably override the other. Unavoidably, intelligent judgment will be required in cases of conflict, or at least for general classes of conflicts. Ultimately, judicial resolution of conflicts between free speech and equal protection claims is based on a largely intuitive process including reflection on matters of dignity. ${ }^{11}$

Though both the speaker and the nonspeaker (or target) in free speech versus equality cases can often characterize their arguments in dignitybased terms, the opposing dignity claims need not be equally strong. In a given case, one party's dignity may be under direct and intentional attack in a particularly crucial way, with a variety of important long-term effects. Even in such difficult cases, it is not necessary that conflict resolution between free speech and equal protection claims be arbitrary, unprincipled, or based merely on individual preferences. ${ }^{12}$

The focus of this Article will thus be on the increasingly important area of conflicts between free speech and equal protection. But it must be emphasized that dignity-based approaches to conflicts between other rights are also possible. Dignitary considerations, for example, seem appropriate in explaining cases in which a free speech defense is raised in a statutory Title VII workplace sexual harassment case. ${ }^{13}$ Dignitary

10. This is not to suggest that free speech and equal protection can never be compatible or mutually supportive. See infra Part V.A. Both opposing parties can often raise plausible equality or free speech claims. In fact, free speech values are likely in one or more respects to appear on both sides of any free speech case. See R. George Wright, Why Free Speech Cases Are as Hard (And as Easy) as They Are, 68 TENN. L. REV. 335, 336 (2001).

11. See R. George Wright, The Role of Intuition in Judicial Decisionmaking, 42 Hous. L. REV. 1381, 1406 (2006).

12. But see Gloria Cowan et al., Hate Speech and Constitutional Protection: Priming Values of Equality and Freedom, 58 J. SOC. ISSUES 247, 250 (2002) (stating "there is no principled way of choosing one over another") (quoting john a powell, Worlds Apart: Reconciling Freedom of Speech and Equality, 85 KY. L.J. 9, 19 (1997)). Part of the value of a dignity-based approach may be its ability to transcend conflicts between liberal-republicanism and communitarianism, or whether to begin with a focus on rights or on good lives. See John Charles Evans, Book Review, 9 CATH. SOC. SCI. REv. 2004, available at www.catholicsocialscientists.org (follow "The Catholic Social Science Review" hyperlink) (reviewing IN DEFENSE OF HUMAN DIGNITY (Kobert $\bar{P}$. Kraynak \& Glenn Tinder eds., 2003)).

13. See, e.g., Baty v. Willamette Indus., Inc., 172 F.3d 1232, 1246-47 (10th Cir. 1999) abrogated on other grounds by Boyler v. Cordant Techs., Inc., 316 F.3d 1137, 
considerations may also arise in free speech versus equal protection contexts other than those on which this Article will focus ${ }^{14}$ and even in legal contexts that seem abstract and institutional. ${ }^{15}$ Conflicts between freedom of speech and equality, and directly between freedom of speech and the value of dignity itself, also have international ${ }^{16}$ and comparative c $^{17}$ legal dimensions.

The strategy of this Article in illustrating the mediating potential of dignity in free speech versus equal protection conflicts is straightforward. We will first consider some of the ways in which dignity is actually defined and utilized in some important constitutional contexts. ${ }^{18}$ Allusion to some classic historical accounts of the idea of dignity will expand the frame of reference and increase the range of possible constitutional analyses. ${ }^{19}$ These possibilities are then tested and refined through reference to some interesting contemporary treatments of the idea of dignity. ${ }^{20}$

The Article will clarify some background relationships between general concepts of freedom and equality ${ }^{21}$ before addressing relationships

1142 (10th Cir. 2003); Greene v. A. Duie Pyle, Inc., 371 F. Supp. 2d 759, 763 (D. Md. 2005); Robinson v. Jacksonville Shipyards, Inc., 760 F. Supp. 1486, 1534-36 (M.D. Fla. 1991).

14. We can imagine rethinking the free speech and equality dimensions of many areas of the law in terms of dignity. See, e.g., Nike, Inc. v. Kasky, 539 U.S. 654 (2003) (involving corporate speech in relation to working conditions in foreign factories); Barnes v. Glen Theatre, Inc., 501 U.S. 560 (1991) (involving commercial nudity); Rust v. Sullivan, 500 U.S. 173 (1991) (involving government subsidized speech); Buckley v. Valeo, 424 U.S. 1 (1976) (involving electoral spending regulation).

15. For possible conflicts between aspects of free speech and equality or equal protection, see generally Nicholas Wolfson, Equality in First Amendment Theory, 38 ST. LouIS U. L.J. 379 (1994) (referring to issues such as campaign spending, campaign contributions, and media concentration).

16. See, e.g., Sean D. Murphy, Hate-Speech Protocol to Cybercrime Convention, 96 AM. J. INT'L L. 973, 974-75 (2002).

17. See generally Ernst Benda, The Protection of Human Dignity (Article I of the Basic Law), 53 SMU L. REV. 443 (2000); Ronald J. Krotoszynski, Jr., A Comparative Perspective on the First Amendment, 78 TUL. L. REV. 1549 (2004); Laura R. Palmer, A Very Clear and Present Danger: Hate Speech, Media Reform, and Post-Conflict Democratization in Kosovo, 26 YALE J. INT'L L. 179 (2001). For the leading Canadian hate speech case, see The Queen v. Keegstra, [1990] 3 S.C.R 697 (discussing high school class time devoted to anti-Semitic teachings). For a discussion of Keegstra, see, for example, Mayo Moran, Talking About Hate Speech: A Rhetorical Analysis of American and Canadian Approaches to the Regulation of Hate Speech, 1994 WIS. L. REV. 1425. For a recent significant European controversy, see the discussion of the group defamation suit brought by William Goldnadel against Le Monde among other defendants in Craig $\mathrm{S}$. Smith, Europe Struggles with Boundaries of Free Speech, INT'L HERALD TRIB., www.iht.com/articles/2005/06/21/news/paris.php (last visited Oct. 15, 2006).

18. See infra Part II.

19. See infra Part III.

20. See infra Part IV.

21. See infra Part V.A. 
specifically between freedom of speech and equal protection. ${ }^{22}$ The best understandings of human dignity are then applied to more specific contexts involving hate speech, ${ }^{23}$ including the distinct problem of Confederate flag display in public schools. ${ }^{24}$ A brief conclusion reinforces the value of dignity in explaining and resolving important conflicts between free speech and equal protection. ${ }^{25}$

22. See infra Parts V.B.-C.

23. See infra Part V.B.

24. See infra Part V.C.

25. See infra Part VI. Note that the strategy of seeking to mediate between free speech and equal protection on the basis of a particular value hardly requires that the chosen value be that of dignity. In this context, john a. powell suggested the value of "participation." See powell, supra note 12, at 13-14, 66-69. The idea of participation can certainly be linked to freedom of speech and equal protection. But focusing on participation rather than on dignity involves several disadvantages for the purposes of this Article.

One might first question whether the value of participation carries enough "fundamentality" and leverage to do the work required. One can imagine a reasonable person's apathy toward participating in decisionmaking if his or her freedom of speech and rights to equality are otherwise protected. Not participating may reflect reasonable confidence in one's colleagues, in the process of decisionmaking, or in the outcome. Not caring about one's dignity in some fundamental sense, however, seems much less understandable and more disturbing. Dignity thus carries more gravity and is less entirely optional than the choice to participate in some process.

Additionally, the idea of participation can be clarified only by deciding in advance the scope, value, and priority of freedom of political speech and equality in collective decisionmaking and the equal protection of the laws. The value of participation, therefore, depends upon the value of freedom and of equal protection of the laws. The idea of dignity, on the other hand, can be sufficiently described without relying on the idea of freedom of speech or even of equality in general. Kant's approach to dignity, for example, depends upon absolutism, non-comparability, and on the non-interchangeability of persons far more than upon the idea of equality. See infra Part III.

Before one can make the idea of participation meaningful, one must already have decided upon the scope of freedom of speech on public issues and of equal protection in decisionmaking. Participation, one must ask, in what? To what extent? In which ways? Participation can be either "thin" or "thick," direct or indirect, intensive or distant and attenuated, and so on. The more seriously protection is extended to some forms of equality and freedom of speech, the richer and fuller the varieties of participation that will likely ensue. It seems unworkable to decide on the meaning and proper scope of participation without having first settled the contours of public-issue free speech and equal protection in collective decisionmaking.

Freedom of speech is often thought to serve democratic decisionmaking, among other values. See, e.g., Kent Greenawalt, Free Speech Justifications, 89 CoLUM. L. REV. 119 , 145-46 (1989). And it may be that persons cannot be autonomous in a rich and full sense of the term if they are excluded from all opportunities to participate in decisionmaking. But even if these arguments could be expanded, we would stili not have a ciear and independent prior idea of valuable participation. The best we could hope for would be a sort of mutually helpful circularity, defining participation on the one hand and deliberative political free speech and equal protection in decisionmaking procedures on 


\section{The Dignity OF THE PERSON: SOME CONSIDERATIONS FROM THE GENERAL CASE LAW}

We will need to develop an understanding of dignity that can properly mediate between the conflicting demands of free speech and equal protection. The case law by itself does not fully articulate such an understanding of dignity. Nor can the case law by itself fully justify the use of the idea of dignity as a mediator between constitutional provisions.

The cases can, however, provide a flavor of the current use of the idea of dignity in one or more relevant senses. The case law can also introduce us to relationships between dignity, freedom, and equality. ${ }^{26}$ We can then survey the most useful meanings of dignity ${ }^{27}$ and apply our results in the context of some conflicts between free speech and equal protection. $^{28}$

A first step in sorting out meanings of dignity considers what we ordinarily assume to oppose or violate dignity. At this early stage, we can look mainly for convention rather than for precision, depth, or sophistication. The case law provides references to a number of ideas and practices in tension with the basic idea of human dignity.

Most starkly, the idea of brutality certainly seems readily opposed to that of dignity. The tension, if not the direct opposition, between brutality and dignity has been judicially implied in a number of cases. The Supreme Court has accordingly recognized that "[c]onvictions based on evidence obtained by methods that are 'so brutal and so offensive to human dignity' that they 'shock the conscience' violate the Due Process Clause." 29

the other. The idea of dignity as elaborated by Kant, among others, requires no comparable circularity.

26. See infra Part II.

27. See infra Parts III-IV.

28. See infra Part V.

29. Chavez v. Martinez, 538 U.S. 760,774 (2003) (quoting the classic case of Rochin v. California, 342 U.S. 165, 172, 174 (1952), which overturned a conviction based on evidence obtained by pumping the defendant's stomach without consent). Chavez involved a $\S 1983$ action alleging a coercive police interrogation after the suspect-plaintiff had been allegedly shot by an officer. Id. at 764; see also Thompson v. Souza, 111 F.3d 694, 701 (9th Cir. 1997) (quoting Vaughn v. Ricketts, 859 F.2d 736, 742 (9th Cir. 1988)). Thompson involved an alleged visual strip search of a prisoner's body cavities and an alleged involuntary urinalysis test. See id. at 696-97. Vaughn involved a more intrusive alleged physical search. See Vaughn, 859 F.2d at 742 . For a relevant discussion of Chavez, see Renda v. King, 347 F.3d 550, 558 n.4 (3d Cir. 2003). 
The related idea of barbarity also helps in arriving at an understanding of dignity, ${ }^{30}$ as the idea of civilized behavior does more positively. ${ }^{31}$ The legal concept of "cruel and unusual punishment"32 has also been described as fundamentally opposed to human dignity, ${ }^{33}$ as have the related ideas of torture ${ }^{34}$ and of "harsh or humiliating treatment." 35

Certain kinds of treatment can be classified under headings that ordinarily stand in opposition to the dignity of the person. The severity of any offense against dignity, however, may vary widely within the range of each general heading. A dignitary violation of bodily intrusion, for example, may range from allegedly coerced blood tests, ${ }^{36}$ through any sort of unconsented-to medical experimentation, ${ }^{37}$ to surgical alteration of the body, ${ }^{38}$ or alleged sexual assault by a prison guard. ${ }^{39}$

30. See, e.g., United States v. Gementera, 379 F.3d 596, 598, 608 (9th Cir. 2004) (upholding a release condition requiring a prisoner to wear a sign reading "I stole mail. This is my punishment.").

31. See id.

32. U.S. CONST. amend. VIII.

33. See Gementera, 379 F.3d at 608 (citing Trop v. Dulles, 356 U.S. 86, 100 (1958)).

34. See Nuru v. Gonzales, 404 F.3d 1207, 1222 n.11 (9th Cir. 2005) (citing international authority) (asylum application case).

35. Id.; see also Jones v. Cuningham, No. 03-15948, 2004 WL 500998, at *1 (9th Cir. Mar. 12, 2004) (alleging humiliation through forced exhibitionism of prisoner) (citing Schwenk v. Hartford, 204 F.3d 1187, 1197 (9th Cir. 2000) (alleged prison sexual assault case)).

36. See, e.g., Marshall v. Columbia Lea Reg'l Hosp., 345 F.3d 1157, 1171 (10th Cir. 2003) (alleging coerced warrantless blood test associated with traffic stop).

37. See, e.g., Skinner v. Oklahoma, 316 U.S. 535, 546 (1942) (Jackson, J., concurring) ("There are limits to the extent to which a legislatively represented majority may conduct biological experiments at the expense of the dignity and personality and natural powers of a minority....") (enforced sterilization of multiple-conviction prisoner) (addressing Buck v. Bell, 274 U.S. 200, 207 (1927) (Justice Holmes pronouncing, in a sterilization case, that "three generations of imbeciles are enough.")). Also see the more recent case of United States v. Stanley, 483 U.S. 669, 671 (1987), involving the alleged secret administration to service personnel of LSD pursuant to an Army experiment. Justice Brennan observed in Stanley that "[t]he subject of experimentation who has not volunteered is treated as an object, a sample." Id. at 708 (Brennan, J., concurring in part and dissenting in part). Justice Brennan concluded that "[s]oldiers ought not be asked to defend a Constitution indifferent to their essential human dignity." Id.

38. None of the cases referenced in note 37 supra involved genuinely free and voluntary, knowing and informed consent; in each case, the primary intended beneficiary seems to have been society rather than the individual subjected to the invasive bodily intrusion itself.

39. See, e.g., Schwenk, 204 F.3d at 1197. 
More generally, it is entirely common to see some invasions of physical privacy as impinging upon dignity. Thus, for example, "humiliation from ... forced exhibitionism [can be] 'deeply offensive to human dignity." 40 More explicitly, courts have held that "[i]ndividualized suspicion is required for a law enforcement search because ' $[t]$ he interests in human dignity and privacy which the Fourth Amendment protect forbid any such intrusions on the mere chance that evidence might be obtained."

Privacy violations in a broader sense may also oppose human dignity. Judge John Noonan of the Ninth Circuit recently referred in a persecution and asylum case to the congressional belief that China's one child policy is "deeply offensive . . to human dignity."42 In such a case, the central indignity is the imposition of some legal penalty for violating the policy, or coerced compliance with the policy. But even the enactment of the policy itself arguably amounts to an affront to dignity.

We thus have a sense that however we ultimately use it, the idea of dignity must stand in tension with ideas such as brutality, cruelty, torture, humiliation, uncivilized or barbarous behavior, harsh treatment, and various sorts of intrusion and privacy invasion. ${ }^{43}$ We can therefore negatively triangulate the idea of dignity, within limits, even without a more positively developed theory of dignity.

A further lesson is that dignity has a recognized constitutional dimension, and this dimension encompasses a number of constitutional provisions. Infringement of dignity may take the form, for example, of a violation of the Eighth Amendment's prohibition of cruel and unusual punishment. ${ }^{44}$ The Fourth Amendment's prohibition of unreasonable

40. See Jones, 2004 WL 500998, at *1 (quoting Schwenk, 204 F.3d at 1197). There can be indignity without subjective feelings of humiliation or violation on the part of the victim. See, e.g., Doe v. Heck, 327 F.3d 492, 512 (7th Cir. 2003) (noting children may have dignitary interests beyond their limited subjective expectation of privacy); see also Victor Hugo, THE HuNCHBACK OF NoTRE DAME 51-54, 65, 69-70 (Walter J. Cobb \& Phyllis LaFarge trans., Signet Penguin 1965) (1831) (public humiliation of Quasimodo as subjectively unrecognized by the latter).

41. United States v. Sczubelek, 402 F.3d 175, 202 (3d Cir. 2005) (McKee, J., dissenting) (quoting Schmerber v. California, 384 U.S. 757, 769-70 (1966) (involving refusal of a probation officer's requirement to provide a DNA sample)); see also Evans v. Stephens, 407 F.3d 1272, 1296-97 (11th Cir. 2005) (en banc) (Barkett, J., concurring in part and dissenting in part) (quoting Schmerber, 384 U.S. at 769-70) (involving an alleged strip search and body cavity search).

42. Li v. Ashcroft, 378 F.3d 959, 964-65 (9th Cir. 2004) (Noonan, J., dissenting).

43. See supra notes $29-42$ and accompanying text.

44. See, e.g., Hope v. Pelzer, 536 U.S. 730, 738 (2002) (involving the alleged prolonged use of a "hitching post" for inmate discipline). The "basic concept underlying the Eighth Amendment ... is nothing less than the dignity of man." Id. (quoting Trop v. Dulles, 356 U.S. 86, 100 (1958)); see also Furman v. Georgia, 408 U.S. 238, 257, 271 (1972) (Brennan, J., concurring) ("The primary principle is that a punishment must not be so severe as to be degrading to the dignity of human beings.") (death penalty for 
searches and seizures similarly protects dignitary interests. ${ }^{45}$ Dignity may be at the heart of Fourteenth Amendment substantive due process ${ }^{46}$ or procedural due process ${ }^{47}$ claims as well. ${ }^{48}$

More central to our concerns, however, are the relationships between dignity and freedom and between dignity and equality, or more specifically, between dignity and freedom of speech and between dignity and the equal protection of the laws. We will explore the various supporting and conflicting relationships below, focusing on dignity as an intermediator between conflicting free speech and equal protection claims. $^{49}$

The indignities of slavery, caste, segregation, and discrimination implicate both freedom and inequality not just as a matter of ethics but in constitutional substance. Thus the cases recognize the intent of the Constitution's "broad provisions to secure individual freedom and preserve human dignity." 50 This recognition does not strictly imply any

rape); United States v. Gementera, 379 F.3d 596, 608 (9th Cir. 2004) (quoting Trop, 356 U.S. at 100).

45. See, e.g., Schmerber, 384 U.S. at 769-70; Evans, 407 F.3d at 1296-97; Sczubelek, 402 F.3d at 202 (quoting Schmerber, 384 U.S at 769-70).

46. See, e.g., Anderson v. Larson, 327 F.3d 762, 769 (8th Cir. 2003) (alleging unlawful arrest and prosecution) (citing Weiler v. Purkett, 137 F.3d 1047, 1051 (8th Cir. 1998)).

47. Professor Mashaw developed this line of analysis most notably in Jerry L. Mashaw, Administrative Due Process: The Quest for a Dignitary Theory, 61 B.U. L. REV. 885 (1981). See also Humphries v. Ozmint, 397 F.3d 206, 244 (4th Cir. 2005) (en banc) (Wilkinson, J., dissenting) (death penalty prosecutor's alleging "comparative human worth" jury argument) ("[D]ue process at its core contains a commitment to treat all litigants as individuals of equal dignity." (citing Lyng v. Castillo, 477 U.S. 635, 636 n.2 (1986))) (petition for writ of certiorari filed May 18, 2005). The dissenting opinion in Ozmint relied on its interpretation of Payne v. Tennessee, 501 U.S. 808, 823 (1991), which rejected arguments that the death penalty can be a legitimate response to a perceived difference in the life worth of the defendant and victim.

48. This is not to deny the existence of "dignitary torts." See, e.g., DAN B. DoBBS, LAW OF REMEDIES $\S 7.1$, at 259 (1993) (discussing defamation, privacy and emotional distress torts). For an extended sense of "dignity" encompassing a broad range of personal torts, see Allstate Insurance Co. v. Ginsberg, 351 F.3d 473, 479 n.3 (11th Cir. 2003). See also Andrew L. Merritt, Damages for Emotional Distress, in Fraud Litigation: Dignitary Torts in a Commercial Society, 42 VAND. L. REV. 1 (1989). We need not assume that all dignitary torts must involve constitutionally protected interests.

49. See infra Parts V.A.-B.

50. Roper v. Simmons, 543 U.S. 551, 578 (2005) (juvenile death penalty); see also Cohen v. California, 403 U.S. 15, 24 (1971) (discussing freedom of speech as required by "the premise of individual digninity and choice upon which uur political system rests"); Griffith v. City of Des Moines, 387 F.3d 733, 739-40 (8th Cir. 2004) (Magnuson, J., concurring specially) (disparate treatment employment) ("[T] he Civil Rights Act of 1964 was enacted 'to promote a more abiding commitment to freedom, a more constant 
substantive relationship between freedom and dignity. It is possible that constitutional provisions could be intended to serve both freedom and dignity, with no essential overlap. But as we shall demonstrate, this seems unlikely. ${ }^{51}$

The cases similarly recognize the common constitutional dimension of the quest for equality, or for equal protection, and dignity. The Court in $N A A C P$ v. Claiborne Hardware, 52 for example, refers to "the basic rights of dignity and equality that this country had fought a Civil War to secure." $" 53$ Commentary on the case law in the United States ${ }^{54}$ and elsewhere ${ }^{55}$ has pursued the idea of a link between dignity and equality as well. This Article will address the linkages between freedom and dignity and between equality and dignity, and their intermediation, below. $^{56}$

This is not to suggest that only cases discussing dignity explicitly can teach us about the constitutional role of dignity. Consider, for example, the following trial court transcript in which the ideas of speech, equality, and dignity ${ }^{57}$ implicitly support and conflict with one another. The excerpt is introduced in the words of Justices Douglas and Goldberg:

In Hamilton v. Alabama, ... we reversed a judgment of contempt on a Negro witness under these circumstances:

"Cross examination by Solicitor Rayburn:

'Q. What is your name please?'

pursuit of justice, and a deeper respect for human dignity." (quoting President Lyndon B. Johnson, Radio and Television Remarks upon Signing the Civil Rights Bill, in 2 PUB. PAPERS OF LYNDON B. JOHNSON 1963-64, at 842-44 (1965))).

51. See infra Part V.A. At the case law level, as distinct from more theoretical jurisprudence, see, for example, Buchanan v. Warley, 245 U.S. 60, 76 (1917) (discussing the Civil War amendments as promoting both freedom and "equality of civil rights").

52. 458 U.S. $886(1982)$.

53. Id. at 918 . For an attempt to synthesize free speech with equality and dignity in the form of "equal dignity," see Aguilar v. Avis Rent A Car System, Inc., 980 P.2d 846 (1999) (Brown, J., dissenting). "In permitting speech, but requiring the speaker to pay damages for injurious speech, the California Constitution preserves both the freedom of the speaker and the equal dignity of the audience. This compromise not only discourages injurious speech, but may also foster positive change in the speaker's attitudes." Id. at 894.

54. See, e.g., Christopher A. Bracey, Dignity in Race Jurisprudence, 7 U. PA. J. CONST. L. 669 (2005) (discussing the linkage between dignity and equality as nonsubordination and the underutilization of dignity-based analysis in contemporary jurisprudence).

55. Denise G. Réaume, Discrimination and Dignity, 63 LA. L. Rev. 645 (2003) (discussing dignity, as opposed to imputations of lesser worth or lesser respectworthiness, as a key element in Canadian jurisprudence of equality and rights to equality).

56. See infra Parts V.A.-B.

57. This is not to suggest that conscious slights in forms of address reflecting a racial hierarchy should be analyzed in the same terms of indignity as might be most applicable to other constitutional conflicts. 
'A. Miss Mary Hamilton.'

'Q. Mary, I believe - - you were arrested - - who were you arrested by?'

'A. My name is Miss Hamilton. Please address me correctly.'

'Q. Who were you arrested by, Mary?'

'A. I will not answer a question - -

'By Attorney Amaker: The witness's name is Miss Hamilton.'

'A. - - your question until I am addressed correctly.'

'The Court: Answer the question.'

'The Witness: I will not answer them unless I addressed correctly.'

'The Court: You are in contempt of court - -'

'Attorney Conley: Your honor - - your honor - -'

'The Court: You are in contempt of this court, and you are sentenced to five days in jail and a fifty dollar fine."

This incident is fairly bursting with unstated speech, compulsion, equality, hierarchy, deference, and dignity issues. While indignities in the context of speech and inequality can take many culturally dependent forms, ${ }^{59}$ general theoretical approaches to dignity can nonetheless be developed, as discussed below.

\section{SOME CLASSICAL ACCOUNTS OF THE GROUNDS AND MEANINGS OF DIGNITY}

When the law speaks of human dignity, ${ }^{60}$ the meaning and force of its assertions depend on the broader treatments of dignity that have shaped our culture over time. The dependence is inescapable, whether judges are consciously aware of this reliance or not. It is difficult to detect any real difference between judicial opinions that explicitly cite, for example, the relevant work on the dignity of philosopher Immanuel Kant, ${ }^{61}$ and related opinions that cite neither Kant nor any other

58. Bell v. Maryland, 378 U.S. 226, 242, 248 n.4 (1964) (opinion of Douglas and Goldberg, JJ.) (quoting, in a "relic of slavery" context, the record in Hamilton $v$. Alabama, 376 U.S. 650 (1964) (per curiam) (summarily reversing Ex parte Hamilton v. Alabama, 156 So. 2d 926 (1963))); see also ANTONY FLEW, THE POLITICS OF PROCRUSTES: CONTRADICTIONS OF ENFORCED EQUALITY 41 (1981) (noting in connection with Hamilton, 376 U.S. 650, that in some contexts it is possible to utter intentionally or unintentionally demeaning language, not in the form of epithet or argument, but through in some sense not technically or literally incorrect forms of address).

59. See FLEW, supra note 58.

60 . The reference throughout to "human dignity" should not be taken to imply that only human beings are capable of possessing dignity in the relevant sense. The phrase human dignity, suggesting but hardly proving the uniqueness of humans in this respect, is simply entrenched in much of the historical discussion of dignity. References thereto do not imply endorsement.

61. See, e.g., State v. Perry, 610 So. 2d 746, 767-68 (La. 1992). Perry addressed whether the state could medicate an incompetent but unconsenting prisoner for purposes 
philosopher. $^{62}$ Popular versions of philosophical accounts of dignity are an element of the jurisprudential air we breathe. Inevitably, philosophical accounts inform our constitutional case law on the meanings, sources, and roles of dignity.

Let us start near the beginning. Among the ancients, Plato, though not an egalitarian with regard to people's capacities, at least credits every person with the capacity to reason and to apprehend truths. ${ }^{63}$ Plato offers in this respect some elements of an approach to the dignity of the person. Aristotle in turn refers to the life of the intellect as reflecting our highest, best, and truest selves. ${ }^{64}$ A divine element within us, or some sort of relatedness to the divine, becomes an important component of a common historical understanding of the nature of human dignity, as seen below. $^{65}$

In the ensuing Stoic philosophical tradition, the themes of elemental human equality and universal human relatedness, ${ }^{66}$ a common rationality, ${ }^{67}$

of rendering the prisoner competent for execution. Id. at 747. The court explicitly discussed Kantian theory of punishment, crucially concluding that "Immanuel Kant, the leading defender of the severe form of retribution, argued that the state should never do anything to a criminal that humiliates and degrades his dignity as a human being." Id. at 767; see also id. at 779, 781 (Cole, J., dissenting); United States v. Blarek, 7 F. Supp. 2d 192, 200-01 (E.D.N.Y. 1998) ("Immanuel Kant . . . held that only a retributivist theory is properly responsive to the criminal's dignity as a rational agent capable of moral conduct, a dignity which he retains despite his commission of a legal offense." (quoting Leon Pearl, A Case Against the Kantian Retributivist Theory of Punishment: A Response to Professor Pugsley, 11 Hofstra L. Rev. 273, 274 (1982))).

62. See, e.g., Gregg v. Georgia, 428 U.S. 153, 228 (1976) (Brennan, J., dissenting) ("The country has debated whether a society for which the dignity of the individual is the supreme value can ... follow the practice of deliberately putting some of its members to death."); Id. at 229 (discussing the Cruel and Unusual Punishment Clause as requiring that punishment be "consistent with [citizens'] intrinsic worth as human beings-a punishment must not be so severe as to be degrading to human dignity"); Id. at 230 ("[The death penalty is] inconsistent with the fundamental premise of the Clause that even the vilest criminal remains a human being possessed of common human dignity." (quoting Furman v. Georgia, 408 U.S. 238, 273 (1972)); see also DeGarmo v. Texas, 474 U.S. 973, 973 (1985) (Brennan, J., dissenting from denial of petition for writ of certiorari) (quoting language immediately above in Gregg, 428 U.S. at 230). Justice Brennan's language can certainly be thought of as philosophical, and as Kantianinfluenced in particular, but is without explicit reference to Kant's work.

63. Plato, The Republic of Plato, bk. VII, at 232 (Francis M. Cornford trans., 1972) ("[T]he soul of every [person] does possess the power of learning the truth and the organ to see it with ....").

64. See ARistotle, The Nicomachean Ethics, bk. X, at 275-76 (J.A.K. Thomson trans., 1953).

65. See infra notes $68,70-74,78$, and accompanying text.

66. See Marcus Aurelius, MEdTATIONS, bk. IV, at 63 (Maxwell Staniforth trans., 1964) ("[A]ll rational beings are created for one another . . .."); id. bk. VII, at 106 ("[A]Il law is one (namely, the common reason which all thinking creatures possess ....")); id. bk. VII, at 109 (universal brotherhood).

67. See supra note 66. 
and the achievability of godlikeness ${ }^{68}$ or the perfected life ${ }^{69}$ are developed by Marcus Aurelius. Particularly relevant to the developing account of human dignity is the claim by the later Stoic writer Seneca that "there resides within us a divine spirit, which guards us and watches us in the evil and the good we do."70

An even more systematically and thoroughly religious approach to the dignity of the person was developed by writers including Augustine ${ }^{71}$ and Thomas Aquinas. ${ }^{72}$ In this tradition, the commonly shared quality of being created in the image of God is central, and is variously explained and interpreted. But some combination of the equally shared capacity for the exercise of intellect, will, memory, or emotional response forms its core. ${ }^{73}$

With the Renaissance, Pico della Mirandola emphasized precisely what was not fixed and unalterable in presenting his account of human dignity. Instead, Pico emphasized the protean, directable character of our "nature," capable as we are, by free choice, of descending into the

68. See AURELIUS, supra note 66, bk. VII, at 117 ("It is perfectly possible to be godlike....").

69. See id. bk. XI, at 171 ("The good life can be achieved to perfection by any soul capable of showing indifference to the things that are themselves indifferent.").

70. Letter from Seneca to Lucilius (letter XLI), in LETTERS FROM A STOIC 86 (Robin Campbell trans., 1969).

71. One contemporary commentator writes that:

$[F]$ or Augustine being an image of God is an essential feature of the human mind. It is not a title indicating a state of moral perfection, bestowed exclusively on the wise, or upon believers ... however much it abuses its freedom it never stops carrying the image of God in itself. For Augustine, being an image of God is an undeletable character of the human mind. This is why the dignity of the human person is inviolable.

Johannes Brachtendorf, Augustine on Human Dignity, Love of Neighbor, and the Role of the Passions, http://www3.villanova.edu/mission/Brachtendorf/JB3.pdf at 2. (last visited Oct. 1, 2006). Augustine emphasizes the three-in-one multiple unity of an integrated intellect, will, and memory, not merely in special moments of reflective self-awareness, but also in states of sleep or unconsciousness. See id.

72. Aquinas writes in the Summa Theologica that "there is in man a likeness to God; not, indeed, a perfect likeness, but imperfect." THOMAS AQUINAS, I SUMMA THEOLOGICA 469 (Fathers of the English Dominican Province trans., Benziger Brothers, Inc. 1948). More specifically, "man is said to be to the image of God by reason of his intellectual nature ...." Id. at 471 . The use of "intellectual" here is simultaneously too broad and too narrow, as Aquinas then emphasizes that "man possesses a natural aptitude for understanding and loving God; and this aptitude consists in the very nature of the mind, which is commion to all men." $I d$. By the word transiated as "men," Aquinas explicitly intends to include men and women. Id. at 472.

73. For a broader discussion, see Richard C. Dales, A Medieval View of Human Dignity, 38 J. HIST. IDEAS 557 (1977). 
abyss or of soaring to divine heights, and thereby exercising a capacity for freedom, self-direction, and self-construction denied to the beasts and even to the angels. ${ }^{74}$

Further development of the early modern understanding of dignity, deemphasizing our outward inequalities, came from Michel de Montaigne. One commentator suggests that Montaigne emphasized his own humility "as if to prove that a man's worth is all inside, and independent of outward glory." 75 It is further suggested that for Montaigne, "[w]orldly success, ... whether based on good fortune or on real ability, proves nothing of a man's worth; on the contrary, it diverts attention from his true substance and ought to be disregarded.,"76

Montaigne's near contemporary, Shakespeare, famously reflected on the subject of human dignity. For a view perhaps only temporary in its felt enthusiasm, we have Hamlet's "What piece of work is a man, how noble in reason, how infinite in faculties, in form and moving how express and admirable, in action how like an angel, in apprehension, how like a god: the beauty of the world, the paragon of animals ...."77

Later, John Locke's influential account of human dignity more systematically emphasized human equality, the capacity to engage in moral reasoning, and the divine source of human dignity itself. ${ }^{78}$ Locke was especially attuned to political assaults on dignity and freedom. His successor George Berkeley instead emphasized the general efforts of philosophers "to raise and refine humankind, and remove it as far as possible from the brute; . . . to remind them of the dignity of their nature; to awaken and improve their superior faculties, and direct them to the noblest objects . . .."79

74. See, e.g., Giovanni Pico della Mirandola, Oration on the Dignity of MAN (A. Robert Caponigri trans., A Gateway Edition 1956). For a more concise, selective version, see Giovanni Pico della Mirandola, On the Dignity of Man: Oration of Giovanni Pico della Mirandola, Count of Concordia, 3 J. HIST. IDEAS 347, 348 (Elizabeth Livermore Forbes trans., 1942).

75. Abraham C. Keller, Montaigne on the Dignity of Man, 72 PuB. MOD. LANG. Ass'N AM. 43, 54 (1957).

76. Id. (Montaigne's corresponding text is probably from the period 1586-1588). For a comprehensive one-volume source, see MICHEL DE MONTAIGNE, COMPLETE ESSAYS (Donald M. Frame trans., Stanford Univ. Press ed., 1958)

77. William SHAKESPEARE, HAMLET act 2, sc. 2, lines 303-07 (Harold Jenkins ed., Methuen 1982).

78. See John Locke, SeCond Treatise of Civil Government 5-6 (Thomas P. Peardon ed., The Liberal Arts Press 1952) (1689) ("[R]eason ... teaches all mankind who will but consult it that, being all equal and independent, no one ought to harm another in his life, health, liberty, or possessions; for men being all the workmanship of one omnipotent and infinitely wise Maker ... they are ... made to last during his, not one another's pleasure ...."). For exceptionally thoughtful discussion, see generally JEREMY WALDRON, GOD, LOCKE, AND EQUALITY (2002).

79. See George Berkeley, Alciphiron, OR THE Minute PhILosopher IN Focus 44 (David Berman ed., Cambridge Univ. Press 2002) (1732) (character of Crito). 
Summarizing even this extremely condensed pre-Kantian survey cannot be fairly done. But there is certainly value in noticing some of the typologies and classifications that contemporary writers present in summarizing the classical tradition. One such framework cites the following as sources of dignity: the idea of human intellect and free will as reflecting creation in the image of God; humanity as a distinctive reconciliation of crucial opposites such as mind and matter; the sense that humans are the last, highest, most developed element of creation; and some asserted distinctive and special relationship between the human and the divine. ${ }^{80}$

An alternative framework for classifying traditional thought on human dignity emphasizes the subtle difference between the infinite value of persons and the irreplaceability or non-substitutability of persons. ${ }^{81}$ This framework then highlights the importance to personhood of the capacity for rationality; ${ }^{82}$ the capacity for a reflexively self-aware selfconsciousness, ${ }^{83}$ the capacity to choose and act for moral or nonmoral reasons towards some selected purpose ${ }^{84}$ the capacity to value other

Berkeley's successor, David Hume, adopts a more contemporary tack. Hume finds our attitude of "respect" for the distinctive excellences of others explainable as a sort of mixture between pure admiration for excellence and our humility in recognizing our own personal lack of the quality admired in another. See DAVID HUME, A TREATISE OF HuMAN NATURE bk. II, pt. II, $\S$ X (ch. 58) (L.A. Selby-Bigge ed., Oxford Univ. Press, 1968) (1740).

A number of conceptual and psychological issues associated with dignity, respect, contempt, esteem, and self-esteem, along with objective and subjective elements thereof, are explored in HUGO, THE HUNCHBACK OF NOTRE DAME, supra note 40, at 51-54,65, 69-70. Hugo describes the mocking "investiture" of the loathed and feared Quasimodo as the "Pope of Fools" in the following terms:

It is difficult to give an idea of how much pride and beatific satisfaction registered on the usually sad and always hideous visage of Quasimodo as he rode. It was the first moment of self-love he had ever enjoyed .... He took seriously all the ironical applause, all of the mock-respect. Id. at 65 .

80. See Thomas A. Shannon, Grounding Human Dignity, 43 Dialog 113-17. Alternatively, for an exceptionally learned but concise cross-cultural survey of conceptions and rationales for human dignity culminating in a brief discussion of the idea of human dignity in modern German and Israeli law, see Izhak Englard, Human Dignity: From Antiquity to Modern Israel's Constitutional Framework, 21 CARDOzO L. REV. 1903 (2000).

81. See Linda Zagzebski, The Uniqueness of Persons, 29 J. RELIG. ETHICS 401, 419-21 (2001).

82. See id. at 405-06.

83. See id. at 406-08.

84. See id. at $408-10$. 
persons and to act on their behalf; ${ }^{85}$ and finally the value of persons as truly unique, distinctive, individual, and incomparable subjects. ${ }^{86}$

No inventory of perspectives on the meaning, logic, and foundations of dignity can avoid giving a central place to the later contributions of the philosopher Immanuel Kant. The Kantian idea of dignity can be approached through the related idea of respect. Kant discusses respect in the following evocative terms:

Respect is always directed only to persons, never to things. The latter can awaken in us inclination and even love if they are animals ..., or also fear, like the sea, a volcano, a beast of prey, but never respect. Something that comes nearer to this feeling is admiration, and this as ... amazement, can be directed to things also, for example, lofty mountains, the magnitude, number, and distance of the heavenly bodies, the strength and swiftness of many animals, and so forth. But none of this respect. 87

Respect in the sense intended by Kant is thus confined to persons. But more positively, "[e]very human being has a legitimate claim to respect from his fellow human beings and is in turn bound to respect every other." 88 Respect in the basic Kantian sense is thus owed universally, from all persons, to all persons.

Kant is emphatic in a formulation of this point that will bear directly on the problem of hate speech versus equality. ${ }^{89}$ He declares that " $[t]$ o be contemptuous of others ...., that is, to deny them the respect owed to human beings in general, is in every case contrary to duty; for they are human beings." Kant plainly denies that there can be groups of persons undeserving of, or who have forfeited, an exemption from expressions of contempt. And he does not treat expressions of contempt as anything less than an invariable breach of the duty of respect.

On this basis, Kant infers "a duty to respect a human being even in the logical use of his reason, a duty not to censure his errors by calling them absurdities, poor judgment, and so forth ...."91 To condemn all contemptuous mockery, including the relatively civil and restrained

85. See id. at $410-23$.

86. See id. at 415-16.

87. Immanuel Kant, Critique of Practical Reason 66 [5:76] (Mary Gregor trans., Cambridge Univ. Press 1997) (1788) (emphasis omitted). We do have in English a sense of respect in which we say we "respect" the eagle's sharp talons, or we "respect" the cobra's ability to strike quickly. But this sense of respect is akin merely to something like "plan for and behave in accordance with the risk or threat realistically posed." This is clearly some distance from the ideas of respect for a distinguished or an institutional person, or a respect for persons in general.

88. IMMANUEL KANT, THE METAPHYSICS OF MORALS 209 [6:462, § 38] (Mary Gregor trans., Cambridge Univ. Press 1996) (1797) (emphasis omitted).

89. See infra Part V.B.

90. See KANT, supra note 88 , at 209 [6:462 § 39] (emphasis omitted).

91. Id. at 210 [6:462 §39]. 
forms referred to immediately above, is quite inescapably to condemn all sorts of individualized and group based hate speech. Thus, Kant elsewhere condemns even the relatively mild communicative expression translated as "scoffing" as contrary to human dignity. ${ }^{92}$ Speech presumed to violate basic moral duty does not cease to be speech for constitutional purposes. But such speech may present a less agonizing tradeoff against equality values. We can hardly ignore the clear implications of Kant's strictures in reflecting on the constitutional status and comparative constitutional value of hate speech and epithet speech in particular.

We can hardly understand, however, how contemptuous mockery can be contrary to human dignity except to the extent we understand dignity in the first place. Kant distinguishes between dignity and price. ${ }^{93}$ If something "has a price, something else can be put in its place as an equivalent; if it is exalted above all price and so admits of no equivalent, then it has a dignity." 94 Dignity is thus "infinitely above all price, with which it cannot be brought into reckoning or comparison without, as it were, a profanation of its sanctity. 95

If we try to clarify the source of dignity, Kant refers to our capacity for autonomy, ${ }^{96}$ our capacity for free and rational moral choice and moral rulemaking. ${ }^{97}$ But we must distinguish between acting autonomously and

92. IMMANUEL KANT, LeCTURES ON ETHICS 239 (Louis Infield trans., Harper Torchbook 1963) (1930). Among the Kantian commentators, Thomas Hill emphasizes that for Kant, human dignity embodied in rational capacity must be honored in word, gesture, attitude, as well as in deed. Thus "[m]ockery is opposed, whether or not it is effective for the purpose of reform or deterrent, because it reflects a disrespectful attitude toward the humanity of others." Thomas E. Hill, Jr., Humanity as an End in Itself, 91 ETHICS 84, 97 (1980); see also THOMAS E. HILL, JR., DIGNITY AND PRACTICAL REASON IN KANT'S MORAL THEORY 49 (1992) (discussing Kant's rejection of mockery on grounds that it is "contrary to the dignity of humanity" and violative of an "exceptionless" moral duty); CHRISTINE M. KORSGAARD, CREATING THE KINGDOM OF ENDS 211 (1996) ("Kant believes that we cannot know people's most fundamental or intelligible characters. But he censures contempt, calumny, and mockery as much for their disrespectful and ungenerous nature as for their lack of a theoretical basis.").

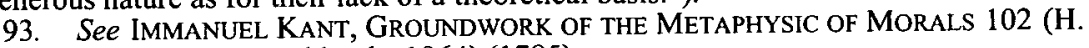
J. Paton trans., Harper Touchbooks 1964) (1785).

94. Id. (emphasis omitted).

95. Id. at 103 . Thus dignity bears, or itself is, "an unconditioned and incomparable worth." Id.

96. See id; see also HILl, DIGNITY AND PRACTICAL REASON IN KANT'S MORAL THEORY, supra note 92, at 47 ("Autonomy is said to be the ground of dignity, and this is a property of the will of every rational being ....").

97. See KANT, supra note 93, at 103 . The incomparable worth of dignity is partly a matter of the fact that "humanity so far as it is capable of morality, is the only thing which has dignity." Id. at 102 . 
our capacity to act autonomously. Autonomy, for Kant, is something like freedom that is rightly used. Autonomy itself involves adopting or adhering to a universal rational moral law. ${ }^{98}$ But it is the broader idea of our freedom, or precisely our mere capacity to act autonomously and thus to act morally rightly or morally wrongly, that is of incomparable worth and that gives us dignity. ${ }^{99}$

Thus Kant does not think that we forfeit our incomparable dignity if we choose to act immorally. ${ }^{100}$ Kant, along with the rest of us, occasionally refers in a colloquial sense to throwing away our dignity by some unworthy, degrading act. ${ }^{101}$ But in a deeper, more fundamental sense, we do not. Kant "repeatedly implies that a person's humanity [or capacity for moral rationality] remains, and so must be respected, even though he defiles, abases, violates, dishonors, or rejects it."102

This certainly means that choosing immorally to engage in hate speech cannot involve any forfeiture of the speaker's own essential human dignity. But it is equally impossible, in Kant's terms, for the targets of hate speech to forfeit their own essential dignity, opening the door to contemptuous mockery or scoffing, let alone to actual hate speech. No one capable of free and rational moral decisionmaking, of consulting a conscience, or of moral praiseworthiness or blameworthiness can be an appropriate object of hate speech. ${ }^{103}$

The attitudes and beliefs underlying much hate speech thus mark the speech as violative of basic Kantian moral principles. Most hate speech, to the extent that it bespeaks any articulable ideas at all, suggests some inferiority or inadequacy of the target group. But for Kant, real or

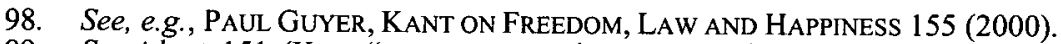

99. See id. at 151 (Kant "sees our capacity to set and pursue ends of our own choice as a fundamental manifestation of our freedom and sees freedom itself as possessing absolute value."); see also KANT, supra note 93, at 103; JOHN RAWLS, LECTURES ON THE HISTORY OF MORAL PHILOSOPHY 211 (Barbara Herman ed., 2000) (For Kant, "[t]he capacity for a good will defines the aristocracy of all."). "[I]t is in virtue of the capacity for a good will that each person has dignity." Id. at 210 ; see also Mark Timmons, Book Review, 104 ETHICs 398, 399 (1994) (reviewing HiLl, DignITY AND PRACTICAL REASON IN KANT'S MORAL THEORY, supra note 92).

100. See Hill, Dignity and PRactical Reason In KanT's Moral Theory, supra note 92 , at 47 . Put somewhat differently, dignity belongs to persons to whom actions and choices can properly be imputed, or "to any finite being who has, or can be presumed to have, a conscience." Susan M. Shell, Kant on Human Dignity, in IN DEFENSE OF HUMAN DIGNITY 53, 56 (Robert P. Kraynak \& Glenn Tinder eds., 2003).

101. Hill, Humanity as an End in Itself, supra note 92.

102. Id.

103. It may be unclear how hate speech could be logically appropriate in the case of targets not meeting the minimum criteria for Kantian dignity. Hate speech directed toward simple animals or mere objects may give them "too much" credit, as though they could be blameworthy. Perhaps, though, what is called hate speech directed at pure abstract ideas or ideologies, or even at general institutions such as slavery, could be logically in order. 
imagined inequalities among persons do not bear upon the shared human dignity that morally bars hate speech. Human dignity is neither achieved through comparative success nor lost through immorality ${ }^{104}$ or real or alleged relative failure, the subtext of much hate speech. What distinguishes people from other persons, favorably or unfavorably, does not confer or negate human dignity. ${ }^{105}$

A bit more elaborately,

[Kantian dignity] attributes a basic worth to all human beings independently of class, talent, achievement, and even moral effort. To acknowledge this worth fully we must do more than respect rights and be charitable; we must value and respect all persons as persons, regardless of status and merit, in attitudes as well as in deed. ${ }^{06}$

Another leading interpreter of Kant expresses this important point in the following terms:

[T]o demand that others earn [respect for their dignity] is in effect to hold that our obligations to others rest (at least in part) on their distinctive excellences rather than fully and unconditionally on their humanity. To require that respect be earned is to hold that people are to be respected in part for what distinguishes them from others ....107

From the Kantian perspective, supposed or even actual instances of inferiority thus cannot justify hate speech, as real or imagined inferiorities cannot detract from the respect owed to all dignity-bearing persons.

This is not to suggest that a Kantian could not recognize a constitutional right to speak or even to act, through speech, in a clearly and deeply immoral way. But a Kantian could certainly take the assumed immorality of speech into proper account in adjudicating cases in which an asserted speech right conflicts with other constitutional values, including equality or equal protection. The free speech versus

104. See supra notes 99-102 and accompanying text.

105. Thus, Kant wishes us to value persons not on what gives them individuality, but on what persons are in common. Hill, Humanity as an End in Itself, supra note 92, at $88 \mathrm{n} .2$.

106. Thomas E. HILl, JR, Autonomy AND SELF-RESPECt 156 (1991).

107. Allen W. WoOd, KanT's Ethical Thought 135 (1999). To carry the implication to more dramatic lengths, Professor Wood argues that Kant holds "that ail the normal (comparative and competitive) measures of people's self-worth-wealth, power, honor, prestige, charm, charisma, even happy relationships with others-are expressions of an utterly false sense of values." Id. at 133. 
equal protection conflict becomes more readily resolvable through the Kantian conception of dignity.

There remains, however, a problem for the Kantian approach to hate speech and equality. In rare cases, the logic underlying hate speech may take an especially radical form. Such cases could go beyond accusations of the inferiority of the target group. The hate speaker could believe the target group lacks the requisites for Kantian dignity, and therefore does not qualify for respect on Kant's own terms.

The idea would be that the target group members are not only inferior in some important respect, but that they lack even the capacity for rational moral decisionmaking, a conscience, or any moral responsibility in the sense of a capacity for genuine praiseworthiness or blameworthiness. ${ }^{108}$ The hate speaker in such a case could agree with Kant about the basic logic of human dignity, and about respecting human dignity, while denying that the targets qualify for respect on Kant's criteria.

Such an approach may seem extreme even among hate speakers. Some hate speakers may not have formulated a precise stance on this question. There may be an incongruity between the speaker's plainly malicious attitude and the supposed incapability of the target group to bear any moral responsibility. Surely some hate speech involves rhetorical exaggeration that is not taken literally even by the speaker.

We should not, however, casually sanitize either the rhetoric or the beliefs of extreme hate speakers. Some hate speech invective carries extreme implications. For example, some groups are referred to explicitly as "subhuman"109 not merely as a matter of history, ${ }^{110}$ but of current-day reality. ${ }^{111}$

108. See supra notes 96-103 and accompanying text.

109. See, e.g., Payam Akhavan, Justice and Reconciliation in the Great Lakes Region of Africa, 7 DUKE J. COMP. \& INT'L L. 325, 347 (1997) (noting that violation of human rights is often preceded by "dehumanization" of the enemy or victim, although often ascribing some degree of residual humanity to the victim, the better to meaningfully hate that victim) (citing Ali A. Mazrui, Human Rights and the Moving Frontier of World Culture, in PHILOSOPHICAL FoundATIONS OF HUMAN RIGHTS 243, 243 (1986)); D. Marvin Jones, Darkness Made Visible: Law, Metaphor, and the Racial Self, 82 GEO. L.J. 437, 459-62 (1993) ("[T]he slave is outside of culture and therefore is nonhuman; is deprived of freedom and therefore is a beast; is voiceless and therefore is an object; is ignorant and therefore is a child."); Girardeau A. Spann, Pure Politics, 88 MICH. L. REV. 1971, 2004 (1990) (noting the Dred Scott-era Supreme Court as adopting a "subhuman-property" position regarding the slavery of the time); infra notes 110-11.

110. See, e.g., Alperin v. Vatican Bank, 410 F.3d 532, 563, 569 (9th Cir. 2005) (Trott, J., concurring in part and dissenting in part) (discussing the Nazi-led Croatian Ustasha regime as viewing some "not as human beings, but as subhuman according to Nazi and Ustasha ideology"); Brown v. Philip Morris Inc., 250 F.3d 789, 810 (3d Cir. 2001) (Shadur, J., dissenting in part) (referring to the center of the historical tobacco growing region as "an area where Blacks were once chattels, viewed as subhuman").

111. See, e.g., Ali v. Ashcroft, 394 F.3d 780, 782 (9th Cir. 2005) (finding insufficient INS rebuttal of asylum-seeker's claim that particular clan members "are 
The term subhuman as used by hate speakers may be ambiguous. It may be possible to be somehow subhuman and still meet the Kantian criteria for dignity. ${ }^{112}$ But the term subhuman hardly requires a belief that those referred to possess the requisites of Kantian dignity. Doubtless such subtleties may be lost on many hate speakers. We would all, however, benefit from a clarification of the basic Kantian theory that could more directly address cases where hate speakers carry the most extreme beliefs about their targets' capacities.

Consider again the cases in which there is a refusal to credit true, full, and nondefective humanity to some target group. The target group is thought to be less than human, not fully human, not truly human, only defectively human, pseudohuman, mere infidel dogs, or devils as opposed to human. ${ }^{113}$ But sucil phrases, without further specification, could conceivably encompass beings who do, and others who do not, meet the Kantian dignitary requirements.

Matters may seem clearer with regard to those thought of literally as "infidels" or as "devils" rather than as human beings. Particularly when the speaker clearly morally blames the purported infidels or devils for their status, is not the speaker conceding the target's possession of the specifically Kantian elements of dignity and respect-worthiness? ? $^{114}$ Does not such a speaker then logically owe us some response to Kant's basic logic?

Unfortunately, this depends on the further details of the speaker's belief system. Some targets may have culpably turned themselves into infidels or devils by their own responsible moral choice. But others may not have. And it is possible that freely becoming an infidel or a devil may be thought to undermine any future capacity for free and rational moral choice, for conscience, or for any future moral responsibility. ${ }^{115}$

bound in servitude to noble Somali families and are considered low-caste and subhuman by other Somali clans"); Peterson v. Wilmur Commc'ns, Inc., 205 F. Supp. 2d 1014, 1015 (E.D. Wis. 2002) (discussing a particular church as allegedly teaching "that all people of color are 'savage' and intent on 'mongreliz[ing] the White Race,' that African Americans are subhuman and should be 'ship[ped] back to Africa' ....").

112. See, e.g., Akhavan, supra note 109, at 347.

113. For a partial inventory of such characterizations in the context of a valuable exploration of the logic of human rights, see MiCHAEL J. PERRY, THE IDEA OF HUMAN RIGHTS: FOUR INQUIRIES 58-59 (1998).

114. Sec supra notes $96-103$ and accompanying text.

115. The degree, if any, to which Dante's Satan, Milton's Satan, or Goethe's Mephistopheles are genuinely capable of repentance has been subject to debate. Some loosely relevant considerations are commonly addressed under what is called the doctrine of 
In such a case, the infidel or devil, however initially voluntarily, would lack now and for the future the elements of Kantian dignity.

In some extreme cases, then, the basic Kantian logic of the grounds of dignity and respect-worthiness would have no logical applicability to the circumstances as supposedly understood by the hate speaker. The Kantian approach would require modification to address such cases. ${ }^{116}$ However, we can reasonably assume such cases to be rare, especially among hate speakers who exhibit the sort of generalized animosity toward their targets that presupposes their target's capacity for moral responsibility.

\section{SOME CONTEMPORARY TREATMENTS OF THE IDEA OF DIGNITY}

For some contemporary writers, the idea of dignity retains an important role in guiding moral and constitutional decisionmaking, with the idea of dignity operating to unify rather than to rank persons. ${ }^{117}$ One contemporary writer, for example, has urged that "[t]hose who try to formulate substantial principles of justice should reserve a prominent place for human dignity. If this is not done, the distinctively moral aspects of justice will be absent; and the claims of justice will be at best legalistic and at worst arbitrary."118

apokatastasis. For historical background, see Edward Moore, Origen of Alexandria and Apokatastasis: Some Notes on the Development of a Noble Notion, 5 QUODLIBET (2003), available at www.quodlibet.net/moore-origen.shtml (last visited Oct. 1, 2006).

116. An alternative approach to adjudicating between free speech rights and equal protection rights would shift the focus to an entirely different Kantian formulation. See Donald L. Beschle, Kant's Categorical Imperative: An Unspoken Factor in Constitutional Rights Balancing, 31 PEPP. L. REV. 949, 954, 963-67 (2004) (focusing on the famous Kantian injunction to never treat persons solely as a means, but always as ends in themselves as well).

117. See, e.g., Michael S. Pritchard, Human Dignity and Justice, 82 ETHICS 299, 301 (1982); Herbert Spiegelberg, A Defense of Human Equality, 53 PHIL. REv. 101, 105 (1944) (noting equality in dignity as reflecting a basic commonality despite differences in contribution).

118. Pritchard, supra note 117 , at 300-01. Pritchard's own suggestion is that "the capacity for developing a sense of dignity is itself a sufficient reason for attributing human dignity to persons." Id at 312 . This approach faces several problems. Our "reactive attitudes" and the survival advantage of developing a subjective sense of entitlement to respect could persist even if there were no underlying basis to the utterly deluded idea that we genuinely possess dignity. Our success in battle, based partly on our belief that we are aided by the gods, does not show that there are such gods. On the other hand, the capacity to formulate any self-reflexive, self-conscious thought at all, regardless of content, might itself amount to such an astonishing miracle as to confer basic dignity. The capacity to take a conscientious stand on any question at all may actually imply the elements of dignity. See supra Part II. 
The idea of the dignity of the person pervades basic modern international legal documents ${ }^{119}$ and appears explicitly in some recently drafted national constitutions. ${ }^{120}$ The legal documents, however, generally do not attempt to define, describe, or account for the dignity of the person. ${ }^{121}$ They thus do not in themselves clarify the idea of dignity.

To help clarify contemporary general ideas of dignity, we may start with synonyms and related ideas. It is thus said that "nothing is so clearly violative of the dignity of persons as treatment that demeans or humiliates them." ${ }^{22}$ This may help account for why hate speech may be said to be contrary to human dignity. The idea of the demeaning or the humiliating seems more vivid, more concrete, and more emotionally infused than the abstract idea of dignity. The positive but abstract idea of promoting human dignity, by itself, can guide our actions and policies only so far. ${ }^{123}$

Beyond recourse to synonyms, some writers have attempted to construct typologies that reflect our contemporary thinking about dignity. One contemporary writer, for example, has suggested a fourpart typology. ${ }^{124}$ The first meaning of dignity on this typology is the dignity of what is referred to as merit. ${ }^{25}$ This sense of dignity is applied to those who hold some office of distinctively high rank or status, gained either through achievement or through birth and inheritance. ${ }^{126}$ This first sense of dignity has little direct relationship to most important contested issues of liberty and equality and can thus safely be ignored for our purposes.

119. See Oscar Schachter, Human Dignity as a Normative Concept, 77 AM. J. INT'L L. 848,848 (1983).

120. See id. at 848 n.2; Izhak Englard, Human Dignity: From Antiquity to Modern Israel's Constitutional Framework, 21 CARDOZO L. REV. 1903, 1926-27 (2000).

121. See Schachter, supra note 119 , at 849.

122. Id. at 850 . Covering somewhat different ground, but to related effect, the philosopher James W. Nickel has argued that "[w]e respect a person's dignity when we protect his life and agency and when we prevent others from imposing treatment that is severely degrading or unfair." James W. Nickel, Poverty and Rights, 55 PHIL. Q. 385, 394 (2005). We can perhaps see why merely mildly unfair treatment might not be an invariable affront to human dignity. But why does "degrading" treatment, even if not at the level of "severely degrading" treatment, not potentially affront human dignity?

123. See Aurel Kolnai, Dignity, in DIGNTTY, CHARACTER AND SELF-RESPECT, 53, 55 (Robin S. Dillon ed., 1995) ("In contrast with moral approval as such, [dignity] has little, if anything, to do with ... 'action-guiding' rule-obedience in any direct sense.").

124. Lennart Nordenfeit, The Varieties of Dignity, 12 HEALTH CARE ANALYSIS $6 \hat{9}$ (2004).

125. See id. at 71 .

126. See id. 
The second sense of dignity is that of a person's particularized moral stature, either high or low. Dignity in this sense is crucially reflective of the character, thoughts, and deeds of the person in accordance with presumed moral law. ${ }^{127}$ Although to comport oneself with dignity in this sense is admirable, it is difficult to see how the typical epithet hurler advances dignity, in this sense, in either the target of the hate speech or in the hate speaker himself. How engaging in hate speech sets a shining example for others to imitate would on such a theory of dignity remain mysterious. It is simply too difficult to adjudicate between free speech and equality in the hate speech context through a sense of dignity that is enhanced in neither the hate speaker nor the target.

The third sense of dignity is likewise important in certain contexts, but cannot be generally decisive in the hate speech context. This sense is that of the dignity of one's self or one's identity, or the dignity of continuity of identity. ${ }^{128}$ While difficult to clarify, the idea here refers roughly to preservation of the integrity of a unified self, integrated and continuous across time and across personal relationships. In extreme cases, social rejection and deprivation might tend to undermine this dignity of identity. ${ }^{129}$ Some persisting instances of hate speech could perhaps lead some targets to question their worthiness and dignity. But the dignity of identity is more central to societal treatment of the very young, the very old, and the severely physically and mentally ill than to the targets of typical hate speech. ${ }^{130}$

The fourth and final sense of dignity bears much more directly and usefully on hate speech problems. This fourth sense is intended to capture most of the contemporary variants of the basic Kantian and international senses of dignity. ${ }^{131}$ The idea is roughly that a sense exists in which dignity is neither gained nor lost by any person's distinctive achievement or failure and is held equally by all. ${ }^{132}$ The grounds of dignity are thought to be one or more crucial qualities held not merely by all persons, but by all persons in permanently equal measure. The existence of a rational capacity, a capacity for autonomy, freedom,

127. See id. at 72 .

128. See id. at 74-75.

129. See id. at 75. It then becomes an empirical question whether hate speech, or more realistically a sustained campaign or even a dominant culture of hate speech, could undermine core beliefs and capacities of target group members. One respondent to Nordenfelt argues that "[h]umiliation works by undermining the victim's own values, so that he or she is no longer able to judge themselves positively or to create a meaningful narrative of their own lives." Andrew Edgar, A Response to Nordenfelt's "The Varieties of Dignity," 12 Health CARE ANalysis 83, 87 (2004).

130. See Nordenfelt, supra note 124 , at 74.

131. See id. at 77-79.

132. See id. at 78 . 
plasticity, indeterminacy of nature, the presence consciousness, or selfconsciousness might well be thought to serve as such grounds.

Dignity in this fourth sense has the greatest potential for adjudicating between free speech and equal protection. But dignity in this most useful sense is actually a family of only partial theories. It is hardly clear, for example, that all of the possible grounds of dignity cited immediately above ${ }^{134}$ individually carry enough moral weight and relevant significance to be adequate to the adjudicatory task. ${ }^{135}$ But there is also the problem of whether they are all found equally in all persons, or else more in some persons than others. ${ }^{136}$

We must also ask whether the talk of equal dignity of persons, with its comparative quantitative overtones, is precisely what we want to say. Should we instead be emphasizing dignity as uniqueness, irreplaceability, inexchangeability, or incomparability, with an emphasis on incommensurability? ${ }^{37}$ Equality is hardly the same thing as incomparability. After all, things that are equal to one another may or may not be substituted for one another without losing meaning and value. So we must ask whether the differences between equal dignity and incomparable or incommensurable dignity matter crucially in our contexts. ${ }^{138}$

Other complications must also be addressed. What precise sorts of acts are really in derogation of dignity? The legal philosopher R.A. Duff offers a negative typology of "degradation," rather than positively of dignity, that focuses on modes of degrading. ${ }^{139}$ Professor Duff distinguishes four modes of degradation. These include, first, "performative degradation," as for example in the institutional act of ceremonially stripping a military officer of an attained rank. ${ }^{140}$ The second mode is "consequential degradation," as when the economic system operates to degrade longterm unemployed job seekers, where such an effect might not be consciously intended by those who operate the economic system. ${ }^{141}$

133. See id.

134. See id.

135. See supra Part III.

136. See Nordenfelt, supra note 124 , at 78 .

137. See id.

138. See id. But cf. powell, supra note 25 (discussing an alternative focus on the value of participation).

139. R.A. Duff, Punishment, Dignity and Degradation, 25 OX. j. L̇eGAL STUD. i 41 , 149-51 (2005); $c f$. supra notes 29-42 (triangulating dignity negatively).

140. See Duff, supra note 139, at 149.

141. See id. at 149-50. 
In contrast, Professor Duff's third category of degradation involves not necessarily actual degradation, but treatment by others as if one were of a lower rank. ${ }^{142}$ This counterfactual degradation is referred to as "expressive degradation." "143 Whether "expressive" degrading treatment can actually degrade the victim is left unclear, ${ }^{144}$ but there is no obvious reason why expressive degradation could not be combined with intended consequential degradation, ${ }^{145}$ as when a person is subjected to a humiliating caste system.

Professor Duff's fourth mode of degradation is subjective in nature. It is a matter of psychologically feeling degraded. ${ }^{146}$ Professor Duff rightly observes that "feeling degraded is neither necessary nor sufficient for being degraded." 147 One might feel degraded only because of one's bloated self-esteem. And there are on the other hand persons who have been degraded without recognizing it. ${ }^{148}$. Degradation and indignity, as well as inequality and lack of freedom, can exist without being recognized or objected to by their victims. ${ }^{149}$

142. See id. at 150 .

143. Id.

144. See id. at 150 n.21.

145. See id. at 149-50.

146. See id. at 150.

147. Id. (emphasis in original).

148. Other than the literary case of Quasimodo, see supra note 79 and accompanying text, we can think of ethnic slurs not understood by non-English speakers, or the obvious gap between the objective and subjective perception requirements in Title VII workplace harassment cases. See, e.g., Harris v. Forklift Sys., Inc., 510 U.S. 17, 21-22 (1993).

Conduct that is not severe or pervasive enough to create an objectively hostile or abusive work environment ... is beyond Title VII's purview. Likewise, if the victim does not subjectively perceive the environment to be abusive, the conduct has not actually altered the conditions of the victim's employment, and there is no Title VII violation.

Id.; Anna-Maria Marshall, Idle Rights: Employees' Rights Consciousness and the Construction of Sexual Harassment Policies, 39 LAW \& SOC'Y REV. 83, 95 (2005) (quoting Harris, 510 U.S. at 21-22).

It is far from clear, however, that in the cases above, no degrading treatment has taken place if the victim fails to subjectively recognize that the treatment is indeed degrading. Suppose an owner hires a young woman precisely in the hopes that she is naïve and inexperienced enough to fail to appreciate the unusual, and unusually degrading, nature of the treatment to which she is subjected. Should we say that the otherwise degrading treatment she receives is not degrading, because only a more experienced worker would have recognized it as degrading and objected? In contrast, the related idea of humiliation may have a more indispensable subjective element.

Id.; see also Daniel Statman, Humiliation, Dignity and Self-Respect, 13 PHIL. PsYCHOL. $523,532(2000)$.

149. For further extensive discussion of the idea of degradation, mostly in the context of references to degradation, torture, or inhuman treatment under the European Convention on Human Rights and with particular application to criminal punishment, see John Vorhaus, On Degradation. Part One: Article 3 of the European Convention on Human Rights, 31 COMMON L. WORLD REV. 374 (2002) and John Vorhaus, On Degradation. 
Professor Duff's negative typology of the forms of degradation is useful, and the various contemporary typologies and accounts of dignity in general enrich our understanding. It seems fair to say, however, that the best contemporary accounts still depend crucially upon the classical elements articulated by Kant. The grounds of dignity, however we choose to elaborate upon them, must preserve something of the absolute, incomparable, and inalienable, as well as the universal equality associated with Immanuel Kant's approach.

To illustrate this point, consider the contemporary work of John Rawls, which focuses not on dignity but on self-respect and on the social bases thereof. ${ }^{150}$ Not surprisingly, Rawls emphasizes the subjective or psychological dimensions involved. ${ }^{151}$ But he recognizes that "selfrespect normally depends upon the respect of others." 152 We generally need validation by others, along with certain material and social conditions, to sustain our sense of the value of our own efforts. ${ }^{153}$ For such reasons, Rawls argues that the parties in his original position would agree upon a "natural duty of mutual respect" "154 requiring mutually civil treatment ${ }^{155}$ for the sake of advancing their own particular projects and purposes, whatever they turn out to be.

It is not clear how much weight Rawls wishes to place on this precontractualist natural duty of mutual respect, and how much on an acceptance of that duty by the contracting parties. But there is also something paradoxical, if not self-defeating, about an ex ante agreement among persons to genuinely esteem the purposes and projects of other people. Can we agree in advance to be genuinely impressed by what we do not now foresee? Can a party guest agree in advance to genuinely like a new appetizer?

We may all be better off in a pragmatic sense if we at least pretend to esteem and validate each other's purposes and projects. But how much will a person's self-esteem be enhanced if he knows that social support

Part Two: Degrading Treatment and Punishment, 32 COMMON L. WORLD REV. 65 (2003).

150. See John Rawls, A ThEORY Of Justice 440 (1971).

151. See id.

152. See id. at 178 .

153. See id; see also Bertram Morris, The Dignity of Man, 57 ETHICs 57, 57 (1946) ("I wish to emphasize the indispensability of man's social relationships, as pertaining to our belief in his dignity and as giving positive content to that notion.").

154. RAWLS, supra note 150 , at 179.

155. See id. 
of his projects is really driven by a sense of duty, or a contractual obligation, or even by a shared desire for the best social outcome? For the esteem of others to be genuinely meaningful, it would have to reflect at least partly sincere appraisal of something like the particular merits of his projects. Rawls' insistence on civility and mutual respect is certainly praiseworthy, but he has not contributed substantially to the underlying logic of genuine respect or civility, in hate speech or any other context. ${ }^{156}$

Some contemporary writers have taken a significantly different approach to dignity. Professor Robert Goodin makes the classical observation that "we respect people's choices . . because we respect people and their innate dignity." 157 The linkage between freedom and dignity in Goodin's formulation is more explicit than the relationship between equality and dignity, but there is a classic, traditionalist logic supporting this structure. ${ }^{158}$ Interestingly, Professor Goodin argues that, as an object of respect, dignity differs significantly from the authority of the Queen or the equality of persons. ${ }^{159}$ The Queen's authority and the equality of persons exist independently of and precede the decision to respect them. ${ }^{160}$ Human dignity supposedly does not. Goodin asserts that human dignity is mysteriously created, or conjured into being in the first place, by the very act of respecting it. ${ }^{161}$

For Professor Goodin, this curious result only adds to the importance of human dignity. He interprets this to mean that human dignity is a basic presupposition within our ethical and legal beliefs. ${ }^{162}$ As a a logically primitive premise, it cannot be directly argued for or directly supported by other beliefs. ${ }^{163}$ In contrast, we could easily imagine that qualities such as self-consciousness, the capacity for autonomy, or the capacity for free choice should play a crucial role in accounting for the idea of dignity. Professor Goodin's conclusion that human dignity is an axiom and that dignity comes paradoxically into existence only in the very act of being respected leaves such dignity in a precarious position.

156. For a broader critique, see RoBERT NOZICK, ANARCHY, STATE, AND UTOPIA 214 (1974) ("One doubts that the unexalted picture of human beings Rawls' theory presupposes and rests upon can be made to fit together with the view of human dignity it is designed to lead to and embody.").

157. Robert E. Goodin, The Political Theories of Choice and Dignity, 18 AM. PHIL.

Q. 91,91 (1981); see also id. at 94.

158. In addition to dignity, Goodin also explores ideas of autonomy, capacity for choice, and the capacity for reflexive self-consciousness. See id. at 96.

159. See id. at 97.

160. See id.

161. See id.

162. See id.

163. See id. 
If we choose not to respect and thereby not to conjure up human dignity, no one's dignity is violated.

Can someone have a right to have their human dignity created in the first place ${ }^{164}$ That seems rather question-begging. On what grounds would we recognize such a right? Dignitary grounds? On what grounds would we decide whether to bring someone's dignity into being if we can offer no direct argument for the value of dignity? That doing so might somehow pay off? In literally all cases? How would we know the likely consequences of creating this utterly distinctive sort of boot-strapped dignity? In contrast, if we have reason to think that dignity is something that persons have and that is worthy of our respect for actual reasons, the case for respecting dignity become less arbitrary. ${ }^{165}$ History surely teaches that dignity can go disrespected or unrecognized on any scale.

More dramatic that Professor Goodin's approach is the decision of some contemporary pragmatists to drain the metaphysics from all talk of personal dignity. This course is taken for the sake of avoiding confusion and for some presumed pragmatic payoff. Professor Richard Rorty has taken this tack generally, and with specific regard to dignity. ${ }^{166}$ Professor Rorty has argued that, ironically, universal human dignity claims simply speak favorably of some group with which one identifies, relative to some other contrasting group. 167

Such claims raise large issues, 168 and Professor Rorty has not been without his critics on this point. ${ }^{169}$ We need not for our purposes rule out either Goodin's or Rorty's approaches in principle. Our goal is to

164. There may well be senses of dignity, such as exalted status or rank, in which anyone who has fully met the established prerequisites would then hold an entitlement to have the corresponding dignity conferred.

165. For further discussion of some possible relationships between dignity and the possession of rights, see Michael J. Meyer, Dignity, Rights, and Self-Control, 99 ETHICS 520 (1989).

166. See, e.g., Richard RoRTy, OBJECTIVITY, RElativisM, AND TRUTH 312 (1991).

167. See Richard Rorty, Postmodernist Bourgeois Liberalism, 80 J. PHIL. 583, 58687 (1983).

168. See, e.g., R. George Wright, Pragmatism and Freedom of Speech, 80 N.D. L. REV. 103 (2004).

169. See, e.g., Jean Bethke Elshtain, The Equality of Persons and the Culture of Right, 1 U. ST. THOMAS L.J. 5, 10 (2003) ("Radical conventionalism of the sort Rorty advances affords no guarantee of human equality and dignity, hence a culture of rights. Indeed, Rorty here provides a compelling reason for why none of us would wish to live in a world of arbitrary redescription."); Miichaei j. Perry, The Morality of Human Ǩights: A Non-Religious Ground?, 54 EMORY L.J. 97, 147-48 (2005) (emphasizing the ceilinglevel status for Rorty of mere divergent social practices, competing stories, preferences, and sentiments, as opposed to more traditional human rights discourse). 
use human dignity to adjudicate among free speech and equal protection claims. Rorty may pragmatize the idea of dignity in a way that eventually reduces its practical impact. But Rorty's pragmatism may also reduce the metaphysical weight of both freedom of speech and equal protection. Perhaps some proportionality among all three considerations would then remain. ${ }^{170}$ Perhaps dignity, freedom, and equality can all thus happily be metaphysically miniaturized. At this point we are possibly better off erring on the side of inclusion than by simply excluding either Goodin's or Rorty's approach. ${ }^{171}$

For purposes of fairly adjudicating between freedom of speech and equal protection, we need not precisely pin down any unique meaning of the idea of dignity. Perhaps more than one specific understanding of dignity can properly accommodate and adjudicate between free speech and equal protection. What we require of any such understanding of dignity will, however, unavoidably involve several elements. Most importantly, the particular understanding of dignity involved must seem sufficiently weighty, or sufficiently fundamental, to legitimately tip the balance or otherwise resolve cases in which free speech and equal protection conflict.

170. Whether a consistent Rortyan pragmatism would leave things as they are, or even proportionately miniaturized, may be doubted. It seems more likely that the impulse to substantially redistribute resources over time, in a genuinely sacrificial way, from the well off to those less well off, would be especially vulnerable if all groups are reduced to telling stories not aspiring to metaphysical truth. See generally Wright, supra note 168 .

171. Other discussions can be indirectly valuable to our own inquiry, though with a focus on a sense of dignity differing from our own. See, e.g., Avishai MARGalit, THE DECENT SOCIETY 51 (Naomi Goldblum trans., 1996) (stating that as distinguished from self-esteem, "[d]ignity is the tendency to behave in a dignified manner which attests to one's self-respect."); $c f$. id. at 44 ("[R]espect constitutes a ground for treating people equally, while esteem forms a basis for ranking people."); Timothy P. Jackson, The Image of God and the Soul of Humanity: Reflections on Dignity, Sanctity, and Democracy, in RELIGION IN THE LIBERAL POLITY 43, 52 (Terence Cuneo ed., 2005) ("If 'dignity' is identified with the achieved merit of mature selves, then 'sanctity' refers to a gratuitous legacy owned equally by all souls.") (emphasizing the universality of the need for and the ability to flourish only if accorded unconditional care or agapic love); see id. at 64. For a brief review of Religion in the Liberal Polity, see John J. Davenport, Book Review, NOTRE DAME PHIL. REV. (2005), http://ndpr.nd.edu/review.cfm?id=3061 (last visited Oct. 1, 2006). Finally, there is Stephen Darwall's distinction between "recognition respect," the consideration owed to all persons, and "appraisal respect," which is accorded to distinctive excellence. See Stephen L. Darwall, Two Kinds of Respect, 88 ETHICs 36, 3839, 46 (1977). Darwall explains,

The distinction between appraisal respect and recognition respect ... enables us to see that there is no puzzle at all in thinking both that all persons are entitled to respect just by virtue of their being persons and that persons are Id. at 46.

deserving of more or less respect by virtue of their personal characteristics. 
The particular idea of dignity involved must also reflect our common constitutional belief in basic human equality while at the same time not automatically validating the equal protection claim in any conflict with freedom of speech. The idea of dignity must be attributable in full and equal measure to all persons. A constitutional democracy cannot allow for a graded hierarchy of the basic dignity of persons. Yet the idea of dignity must also feed naturally into and help account for the value we attach to freedom of speech. We must be able to see general censorship, for example, as contrary to dignity in the relevant sense, and silencing of conscience as humiliating. These requirements rule out relying on any sense of dignity in which it is more dignified to be, say, a powerful or high-ranking official than a lower-ranking official or ordinary citizen. ${ }^{172}$ Furthermore, from among the otherwise eligible particular understandings of dignity, we would prefer those that are the least generally controversial in their own theoretical assumptions. Thus, among otherwise acceptable particular theories of dignity, those based on narrowly sectarian or otherwise unnecessarily restricted grounds should be disfavored.

Even a theory of dignity as widely influential as Immanuel Kant's can be critiqued to some degree on the latter grounds. Kant, after all, wants to focus not on what he calls our empirical or psychological personality, but on our presumed and admittedly controversial ability to act "independently of the mechanisms of nature." 173 The human ${ }^{174}$ capacity for self-consciousness, or for subjective awareness of our identity as a self, is a matter of the empirical personality rather than of the rational moral personality that is thought by Kant to transcend nature. ${ }^{175}$ Kant's theory of dignity seeks to avoid controversial religious commitments, ${ }^{176}$ but may itself still depend upon discerning "purpose" in nature itself. ${ }^{177}$

172. For an argument that freedom of speech is required to protect human dignity, but that free speech can also undermine the dignity of subordinated persons in particular, see Frederick Schauer, Speaking of Dignity, in THE CONSTITUTION OF RIGHTS, supra note 2 , at 178-79. For discussion of Schauer's approach, see Norman Rosenberg, Dignity, Rights, and Recent Scholarship, 45 AM. Q. 429, 431-32 (1993) (book review). It is precisely the ability to invoke dignity in the same sense both for and against speech that legitimizes its use as a balancing and adjudicating consideration in conflicts between free speech and equal protection claims.

173. See, e.g., ROGER SUlLIVAN, IMMANUEL KANT'S MORAL THEORY 197 (1989).

174. This is not to suggest that members of the human species alone, excluding other animlals, cain be persons or possess dignity in the relevant respect. See supra note 60.

175. See Sullivan, supra note 173 , at 197.

176. See, for example, the classic religiously based theories of dignity discussed supra Part III.

177. See, e.g., Shell, supra note 100, at 68-69. 
It may be that any otherwise suitable theory of dignity must be at least as controversial in its assumptions as that of Kant. If so, this need not unduly disturb us. Theories of freedom and equality are similarly unavoidably controversial. We are seeking a theory of dignity for the purposes of fairly adjudicating between the values of freedom of speech and equal protection. Both freedom of speech $^{178}$ and equal protection ${ }^{179}$ are themselves often thought to be based on premises as deep and controversial as, if not identical to, the grounds of dignity itself.

Some contemporary accounts of dignity actually do attempt to capture the breadth and force of Kant's position, but without any ideas as controversial as ultimate recourse to purposes in nature. ${ }^{180}$ Such accounts unavoidably involve controversy of their own. Professor Alan Gewirth, in particular, starts by assuming that every human is an "actual, prospective, or potential agent ...." ${ }^{\prime 81}$ He then argues that as such, we engage in or at least hold open the possibility of purposive action. ${ }^{182}$ Purposive action implies that the actor ascribes some sort of value to the action undertaken, at least from the standpoint of that very actor. ${ }^{183}$ The valuing of those actions implies that the actor must also value herself, ${ }^{184}$ at least as a reflective chooser whose choices are subjectively worth pursuing. But this logic of valuation then applies not only to the individual chooser herself, but equally to every other purposive actor and to their own value. ${ }^{185}$ By Gewirth's logic, each actor must therefore

178. See, for example, the understanding of self-realization at work in JOHN STUART MILL, ON LIBERTY 75-118 (Gertrude Himmelfarb ed., 1982) (1859).

179. The justifications of the equality of persons, equal protection, and in particular the equal dignity of persons are often ignored or simply taken for granted. For discussion of the justification of equality, see, for example, JOHN E. COONS \& PATRICK M. BRENNAN, BY NATURE EQUAL 33 (1999) ("[P]roperly understood, the capacity for moral personality may not be a 'range property' at all but rather one that is uniform in degree. And if it is uniform, it might be the host property for the relation of human equality."); JEREMY WALDRON, GOD, LOCKE, AND EQUALITY 78-79 (2002) (discussing Locke as grounding equality of rights on each person's equally possessing sufficient ability to reason their way, without revelation, to a recognition of the existence of God and the basic divine moral requirements); George P. Fletcher, God's Image and Egalitarian Politics, 21 SoC. PHIL. \& POL'Y 310 (2004) (concluding that neither John Rawls nor Ronald Dworkin offers much of an account of why all persons should be accorded equal respect in the substantive or procedural dimensions of justice). But $c f$. Serena Olsaretti, Book Review, 114 MIND 750, 751-52 (2005) (reviewing JOHN KEKES, THE ILLUSIONS OF EGALITARIANISM (2003)) (responding to Kekes's claim that modern egalitarianism is effectively groundless).

180. See supra note 177 and accompanying text.

181. Gewirth, supra note 2, at 10, 22.

182. See id.

183. See id. at 21-22.

184. See id. at 22.

185. See id at 23. 
regard all other reflective, purposive, choosing agents, along with herself, "as having worth or dignity."

We need not endorse the full scope of Professor Gewirth's argument as rigorously carrying us to something akin to an egalitarian and robust Kantian sense of human worth as beyond price and not subject to comparison or exchange. Gewirth's theory merely illustrates one approach to human dignity that begins from relatively uncontroversial premises. Other distinct approaches are certainly possible. ${ }^{187}$ And it is again difficult to imagine that anyone can dismiss human dignity in any serious sense, yet also take conflicts between free speech and equal protection to be as deeply meaningful as we ordinarily do. ${ }^{188}$ On this assumption, we can apply a suitable understanding of dignity to potential conflicts of free speech and equal protection.

\section{Dignity and the Mediation of FREE SPEECH AND EQUAL PROTECTION}

\section{A. Some General Relationships Between Freedom and Equality}

Any recourse to dignity to explain and resolve conflicts between free speech and equal protection would be unnecessary if no such conflicts

186. Id. For a critique of Professor Gewirth's argument, as well as of related work by Professors Deryck Beyleveld and Roger Brownsword, see Déirdre Dwyer, Beyond Autonomy: The Role of Dignity in 'Biolaw,' 23 Ox. J. LEGAL STUD. 319, 323 (2003). For further critique, see generally GEWIRTH'S ETHICAL RATIONALISM (Edward Regis, Jr., ed., 1984).

187. Another approach, also egalitarian in its implications, focuses on the astonishing deep inexplicability of human consciousness in general and self-consciousness in particular. See, e.g., DAvid J. Chalmers, The Conscious Mind 93, 106 (1996) ("[C]onsciousness escapes the net of reductive explanation. No explanation given wholly in physical terms can ever account for the emergence of conscious experience."); COLIN MCGINN, THE MYsterious Flame: Conscious Minds in a Material World 5 (1999) (" $[\mathrm{T}]$ he bond between the mind and the brain is a deep mystery. Moreover it is an ultimate mystery, a mystery that human intelligence will never unravel."); KEITH WARD, GOD, CHANCE \& NECESSITY 147 (1996) ("Consciousness . . . . is a mystery that biology can never solve ....."); see also DANIEL C. DENNETT, CONSCIOUSNESS EXPLAINED 22 (1991); OWEN FlanAGan, CONSCIOUSNESS RECONSIDERED xi (1992); Thomas Nagel, What Is It Like To Be a Bat?, 83 PHIL. REV. 435, 435 (1974).

With decidedly more metaphysical baggage, the medieval writer Gregory of Nyassa sought to turn "a philosophical failure into a theological triumph by claiming that the very unfathomability of the human mind is an imitation of the unfathomability of the divine mind and a consequence of man's having been formed in God's image." Richard C. Dales, A Medieval View of Human Dignity, 38 j. Hist. IDEAS 557, 562 (1977). For concision see BERNARD OF Clairvaux, On Loving God, in SElEcted WorKs 173, 176 (G.R. Evans trans., 1987) ("Man's dignity is his free will.").

188. See supra notes $178-79$ and accompanying text. 
ever arose. Unfortunately, such conflicts are in fact sometimes genuine and unavoidable, along with broader conflicts between valuable forms of freedom and equality in general.

One might argue that "freedom and equality, far from being opposed ideals, actually coincide." 189 Concepts of "oppression," of political dominance and subordination, or of civil rights and liberation movements clearly involve allied themes of freedom and equality. ${ }^{190}$ Yet when an employer seeks to raise a free speech defense to claims of unequal treatment on grounds of sex, ${ }^{191}$ we must say more than that the employer simply does not know how to apply the dictionary meanings of freedom and equality.

Part of the problem of the relations between freedom and equality is the number of important dimensions of freedom. ${ }^{192}$ There may be empirical as well as normative dimensions in measuring and assessing freedom. ${ }^{193}$ Freedom may also have instrumental as well as intrinsic value. ${ }^{194}$ Equality, no less than freedom, may take on a plurality of competing values and meanings. ${ }^{195}$

Thus we may well face circumstances in which either freedom or equality must be somehow traded off against itself. These tradeoffs may be unavoidable even if we can still somehow conclude that we have chosen an outcome that maximizes freedom, or an outcome that maximizes equality. Some persons may have less freedom because of a policy that increases freedom overall. ${ }^{196}$ But tradeoffs within valuable forms of freedom and within valuable forms of equality will be inevitable. $^{197}$

189. RichaRd NORMAN, FREE AND EQUAL 133 (1987).

190. See id. (positing that a struggle against oppression may equally be presented as a struggle for freedom or for equality).

191. The following provide illustrations of such genuine conflicts, however anyone wishes to resolve them: Baty v. Willamette Indus., Inc., 172 F.3d 1232, 1246-47 (10th Cir. 1999), abrogated on other grounds by Boyler v. Cordant Techs., Inc., 316 F.3d 1137,1142 (10th Cir. 2003); Greene v. A. Duie Pyle, Inc., 371 F. Supp. 2d 759, 763 (D. Md. 2005); Robinson v. Jacksonville Shipyards, Inc., 760 F. Supp. 1486, 1534-37 (M.D. Fla. 1991) (discussing and ultimately rejecting seven distinct asserted free speech challenges to a Title VII employment discrimination case).

192. See, e.g., IAN CARTER, A MEASURE OF FREEDOM 23, 43, 146, 163, 290-91 (1999). See generally FELIX E. OPPENHEIM, DIMENSIONS OF FREEDOM (1961).

193. See CARTER, supra note 192, at 146, 163; MATTHEW H. KRAMER, THE QuALITY OF FREEDOM 387 (2003) (discussing overall freedom as partly evaluative).

194. See CARTER, supra note 192, at 291.

195. See Paul M. Sniderman eT AL., The Clash of Rights 244 (1996) ("Equality itself is a plurality of values, inviting not merely different but conflicting understandings."); R.M. Hare, Liberty and Equality: How Politics Masquerades as Philosophy, in LIBERTY AND EQUALITY 1, 3 (Ellen Frankel Paul et al. eds., 1985). (2000).

196. See, e.g., T.M. WILKINSON, FREEDOM, EFFICIENCY AND EQUALITY 77-78

197. See Christine Swanton, Freedom 190 (1992). 
Nor can we entirely avoid conflicts between valuable understandings of freedom and equality. There will be tradeoffs between, say, meaningful economic freedoms of one sort or another, and many forms of economic equality. ${ }^{198}$ More generally, and despite their frequent mutual supportiveness in crucial respects, "freedom and equality... coexist in a state of tension ...."199 Meaningful conflicts, the best resolution of which may be controversial, are thus at times inevitable. ${ }^{200}$

This conclusion is unavoidable unless either freedom or equality is redefined in some way that precludes conflicts. There can be no principled objection to redefining any term if the value of doing so is sufficient. But redefining a crucial term such as liberty or equality may well impose costs beyond those of confusion.

The contemporary legal theorist who most famously minimizes disturbing conflicts between liberty and equality is Professor Ronald Dworkin. $^{201}$ Professor Dworkin rightly notes that we can define liberty or freedom in a number of different ways, depending upon what we aim to accomplish through our definition. ${ }^{202}$ As Professor Dworkin recognizes, our political culture thinks of freedom in terms of the absence of obstacles, generally socially or culturally imposed obstacles, to the exercise of deliberation and choice. ${ }^{203}$ And as Professor Dworkin appreciates,

The choice about which freedoms to foster is a social choice, and the way it is made will determine whether the society is dominated by the pursuit of virtue, the cult of the market, the revolutionary spirit, the advocacy of self-criticism, and so on.... [T] among an adequate and reasonable set of incommensurable options.

Id.

198. See Jan Narveson, Equality vs. Liberty: Advantage, Liberty, in LIBERTY AND EQUALITY, supra note 195, at 33, 34.

199. JOHN KeKES, THE MORALITY OF PluRALISM 54 (1993). Kekes states, more controversially, that "the more we have of one, the less we can have of the other." Id. But it seems possible, as in the case of some liberation movements, to dramatically increase crucial freedoms and equality overall at the same time. See, e.g., WILKINSON, supra note 196, at 5-7.

200. This was a major theme of Lord Isaiah Berlin. See ISAIAH BERLIN, Two Concepts of Liberty, in LIBERTY 166, 200-03 (Henry Hardy ed., 2002); see also David B. Wong, Coping with Moral Conflict and Ambiguity, 102 ETHICs 763, 770 n.16 (1992) (citing Two Concepts of Liberty, supra).

201. For a general formulation, see Ronald Dworkin, Foundations of Liberal Equality, in EQUAL FREEDOM 190, 194 (Stephen Darwall ed., 1995).

202. For Professor Dworkin's most specific discussion of such, see Ronalu Dworkin, Do Liberal Values Conflict?, in THE LEGACY OF ISAIAH BERLIN 73 (Mark Lilla et al. eds., 2001).

203. See id. at 83-84. 
freedom in this familiar sense may well conflict with equality as conventionally defined. ${ }^{204}$

Professor Dworkin then asks, however, why we should feel bound by that familiar sort of definition of freedom. He crucially suggests that "liberty isn't the freedom to do whatever you might want to do; it's freedom to do whatever you like so long as you respect the moral rights, properly understood, of others."205 This amounts to a moralized, and in some sense a correct or objective, morality based definition of freedom.

Thus, if hurling a racial epithet at a passing student violates the moral rights of the target, no freedom is lost by restricting the speaker. The speaker by definition suffers no relevant and significant loss of freedom. What we might otherwise see as a conflict between the speaker's freedom and the target's own freedom and equality rights would be short-circuited. The conflict never arises, with the key determination being the scope of the target's genuine moral rights.

We can for present purposes assume with Dworkin that there are objective, ${ }^{206}$ and presumably recognizable, moral rights. It will nevertheless seem odd to say with Dworkin that we cannot tell whether confining an unconsenting person limits that person's freedom of movement until we have properly assessed the confined person's moral rights. Whether the person's freedom has been restricted in accordance with their actual moral rights seems a different and open question.

However, the basic problem with Professor Dworkin's redefinition of freedom, including presumably of freedom of speech, is that it exchanges something of value for an insufficient return. Calling our decision to respect or not respect someone else's moral rights a matter of our socially free choice may be important to our sense of social responsibility and, indeed, to our own dignity as persons. If we do not have a socially free choice between respecting and violating the moral rights of others, we are therein diminished as persons.

Think also in terms of our sheer capacity for action. Suppose we chose, freely or not, to have our brains rewired so that we were prevented, at the last possible moment, from violating anyone's moral rights. Our target's moral rights would certainly be more secure. But, as above, our loss of social freedom and dignity, whatever the remaining alternative vocabulary, would be substantial. We would still have to debate and ascertain the proper scope of everyone's moral rights.

204. See id.

205. Id.

206. See Ronald Dworkin, Objectivity and Truth: You'd Better Believe It, 25 PHIL. \& PuB. AfF. 87 (1996). 
Dworkin's scheme is odd because we would have to somehow delimit everyone's moral rights with no reliance on the crucial idea of freedom.

A less ambitious but also less problematic approach would concede the possibility of conflicts between valuable forms of freedom and equality, but would argue that such conflicts can be minimized in a properly ordered society. Professor Kai Nielsen, for example, argues broadly that "it is only in an egalitarian society that full and extensive liberty is possible."207 But Professor Nielsen's version of radical egalitarianism would inevitably restrict some plainly valued liberties and rights to noninterference. ${ }^{208}$ In this sense, genuine and substantial conflicts between freedom and equality are inescapable. Nielsen's argument, however, is that radical egalitarianism's restrictions on some freedoms can be better justified than the restrictions on freedoms necessarily required by any competing system. ${ }^{209}$ This is certainly possible. Focusing on dignity might well help properly adjudicate such claims, but further addressing Professor Nielsen's broad-scale views on the merits is beyond the scope of this Article.

Despite the inevitable conflicts between freedom and inequality, there is an equally inescapable sense that dignity is somehow related to both. It seems reasonable to suppose that respect for the dignity of persons requires that we treat persons as equals in at least some important respects. ${ }^{210}$ At the same time, respect for dignity also seems to require at least some scope for important individual freedom and judgment. ${ }^{211}$ The idea that dignity is strongly linked to both freedom and equality has also been explicitly recognized. ${ }^{212}$ We take up some of these linkages in the free speech context immediately below.

207. Kai Nielsen, Equality AND LiberTy 302 (1985). Similar themes constitute the utopian vision of EDWARD BELLAMY, LOOKING BACKWARD (Daniel H. Borus ed., St. Martin's Press 1995) (1888).

208. See NIELSEN, supra note 207, at 302-04.

209. See id.

210. See Schachter, supra note 119, at 851 (discussing more specific possible views).

211. See Luis Recaséns-Siches, Dignity, Liberty, and Equality, in 1 EQUALITY AND FREEDOM: INTERNATIONAL AND COMPARATIVE JURISPRUDENCE 3, 9-10 (Gray Dorsey ed., 1977) ("The idea of dignity of the human person necessarily implies the principle of individual liberty.").

212. See Stanley I. BenN, A Theory of FreEdom 117 (1988) ("[O]ne can derive from the principle of respect for persons not onity the principle of noninterference, but also a principle of equal consideration for the interests of persons."). Thus, Professor Benn concludes that genuine respect for persons, or for dignity, implies at least some degree of respect for some forms of liberty as well as equality. 


\section{B. Freedom of Speech, Hate Speech, the Equal Protection of the Laws, and the Dignity of the Person}

Racially charged and other forms of epithet speech are notoriously common on public university campuses and other spaces subject to both free speech and equal protection requirements. ${ }^{213} \mathrm{~A}$ crucial problem in legally addressing such hate speech, however, is the unresolved status of the relationship between freedom and equality discussed above. ${ }^{214}$ The uncertain relationship between freedom and equality generally translates into uncertainty between protecting free speech, including hate speech, and promoting equal protection. Thus we find parallel contrasts of views in the free speech versus equal protection contexts. One scholar asks:

Does the speech right protect precisely the same human characteristics that underlie the goals of social equality? If so, then suppressing speech as a means of achieving social equality is a logical impossibility.... [and] the Equal Protection Clause cannot be understood to dominate - or even to clash withfree speech protection. 215

It is thus argued that restricting speech can neither expand freedom of speech nor promote the equal protection of the laws.

In contrast, "[t]he . . charge issued by radical critics is aimed at the liberal system of free expression, and the heart of the accusation is that the system unduly obstructs efforts to eliminate oppressive inequalities rooted in sex and race."216 The "heroic" free speech ideal under "the guise of liberty, neutrality, and openness ... reinforces existing social and political relationships of dominance and subordination and thus legitimates prejudice and inequality." 217 Such formulations thus emphasize

213. See, e.g., Michelle Boorstein, Slurs at U-Va. Undermine Efforts to Thwart Racism, WASH. POST, Sept. 22, 2005, at B01, available at www.washingtonpost.com/ wpdyn/content/article/2005/09/21/AR2005092102324.html (last visited Oct. 1, 2006); Susan Kinzie, Racist Incidents Unnerve U-Va., WASH. PoST, Sept. 17, 2005, at B01, available at www.washingtonpost.com/wp-dyn/content/article/2005091601896pf.html (last visited Oct. 1, 2006) ("Just a few weeks into the school year, U-Va. has had at least nine racist incidents-slurs shouted from cars, ugly words written on message boards, a racist threat scrawled on a bathroom wall.").

214. See supra Part V.A.

215. John M. Blim, Undoing Our Selves: The Error of Sacrificing Speech in the Quest for Equality, 56 OHIO ST. L.J. 427, 430-31 (1995).

216. Andrew Altman, Equality and Expression: The Radical Paradox, 21 Soc. PHIL. \& POL'Y 1, 2 (2004) ("[I]t is now claimed that the liberal state's strong protection of expressive liberty creates indefensible obstacles to the pursuit of racial and sexual equality.").

217. Mary Ellen Gale, Reimagining the First Amendment: Racist Speech and Equal Liberty, 65 ST. JOHN's L. REV. 119,140 (1991). It is worthwhile to refer to the sustained and developed arguments of Professor Richard Delgado. Richard Delgado, Are HateSpeech Rules Constitutional Heresy? A Reply to Steven Gey, 146 U. PA. L. REv. 865, 865 (1998) ("[I]nterests of equality and dignity might sometimes justify limits on what 
the conflicts between some conceptions of free speech and of equal protection of the laws.

Not surprisingly, some analysts recognize free speech ${ }^{218}$ and autonomy $y^{219}$ values on both sides of the hate speech versus equal protection conflict, as in the broader debate over freedom and equality. ${ }^{220}$ Overall, the conflicts we see in the broader debate over freedom and equality are replicated in the narrower context of freedom of speech and the equal protection of the laws. In the free speech-equal protection cases, it remains appropriate to look to our understandings of the dignity of persons to assist us in more fully understanding and resolving the inevitable conflicts. ${ }^{221}$

In the campus hate speech context, a number of arguments have been widely offered in opposition to hate speech regulation. ${ }^{222}$ We can address such concerns only very briefly and selectively, merely to

may be said."); cf. Steven G. Gey, Postmodern Censorship Revisited: A Reply to Richard Delgado, 146 U. PA. L. REV. 1077 (1998). For further reference, see Richard Delgado, Making Pets: Social Workers, "Problem Groups," and the Role of the SPCA-Getting a Little More Precise About Racialized Narratives, 77 TEX. L. REV. 1571, 1580 (1999) ("In the controversy over hate speech ... a free-speech narrative is often developed in a way that advances and encodes white privilege, while cutting short discussion of countervailing equality values."); Richard Delgado \& David H. Yun, Pressure Valves and Bloodied Chickens: An Analysis of Paternalistic Objections to Hate Speech Regulation, 82 CAL. L. REV. 871, 888 (1994) ("The strongest reason for enacting hate speech rules on campuses with a history of disruption is that they are necessary to promote equality."); Jean Stefancic \& Richard Delgado, A Shifting Balance: Freedom of Expression and Hate-Speech Restriction, 78 IOWA L. REV. 737, 750 (1993) (discussing the hypothesis of reciprocal tension and dependence between freedom and equality in this context).

218. See, e.g., Frank I. Michelman, Civil Liberties, Silencing, and Subordination, in THE PRICE WE PAY, supra note 9, at 272, 273 ("The point of raising the issue of silencing is to justify restrictions on freedom of expression in the name of the one value we cannot conceivably rank below freedom of expression, namely, freedom of expression."); Stefancic \& Delgado, supra note 217.

219. See Michelman, supra note 218 (stating "we have autonomy values on both sides"). 220. See supra Part V.A.

221. For a sense of some of the conflicts, and an attempt at a defensible compromise position, see Toni M. Massaro, Equality and Freedom of Expression: The Hate Speech Dilemma, 32 WM. \& MARY L. REV. 211, 248-50 (1991) (articulating an "accommodationist" middle ground position).

222. Among the most concise and comprehensive listings of such concerns are those by Nadine Strossen. See Nadine Strossen, Hate Speech and Pornography: Do We Have to Choose Between Freedom of Speech and Equality?, 46 CASE W. RES. L. REV. 449 (1996); Nadine Strossen, In the Defense of Freedom and Equality: The American Civil Liberties Union Past, Present, and Future, 29 HARV. C.R.-C.L. L. REV. 143, 15051 (1994). Some of Professor Strossen's concerns parallel those commonly raised against clearly progressive reforms such as affirmative action programs. 
illustrate the possible role of dignity-based considerations. Broader responses to such arguments are to be found elsewhere. ${ }^{223}$

It has been argued, for example, that hate speech bans

may reinforce the paternalistic assumption that individuals belonging to certain marginalized groups cannot talk back for themselves, may turn racists into libertarian martyrs, may treat only the symptoms of prejudice while leaving the underlying attitudes untouched, and may open the door to the punishment of unpopular speech. 224

From the standpoint of the fundamental dignity of the parties, recall Immanuel Kant's repeated condemnation of disrespect in the form of contemptuous mockery or scoffing, ${ }^{225}$ such as to rule out epithet speech as incompatible with the dignity of the person. If mere "scoffing" is incompatible with fundamental dignity, how much more so must be the kinds of vicious epithets involved in typical hate speech cases? In such cases, Kantian-influenced understandings of dignity clearly tip the constitutional balance in favor of equal protection as opposed to the free speech rights of the epithet hurler. In this range of cases, on balance, considerations of dignity determinately favor considerations of equality over the rights of a class of speakers. Considerations of basic dignity guide the resolution of conflicting constitutional claims in ways that are not only determinate, but broadly just and legitimate as well.

But let us presume that there is a paternalistic assumption that members of "certain marginalized groups cannot talk back for themselves." 26 Let us match this assumed stereotype against the circumstances of common sorts of campus hate speech incidents. Consider, for example, a slur shouted from a passing car, targeting one or more pedestrians. ${ }^{227}$ The target's opportunities for a meaningful response, let alone a cogent

223. See, e.g., Kent Greenawalt, Insults and Epithets: Are They Protected Speech?, 42 RUTGERS L. REV. 287 (1990); Michelman, supra note 218; powell, supra note 25.

224. Note, The Demise of the Chaplinsky Fighting Words Doctrine: An Argument for Its Interment, 106 HARV. L. REV. 1129, 1141 (1993). The Court in Chaplinsky v. New Hampshire, 315 U.S. 568, 572 (1942) (quoting Cantwell v. Connecticut, 310 U.S. $296,309-10(1940)$ ), urged that " "[r] $]$ esort to epithets or personal abuse is not in any proper sense communication of information or opinion safeguarded by the Constitution, and its punishment as a criminal act would raise no question under that instrument." See also, e.g., Idaho v. Poe, 88 P.3d 704, 719 (Idaho 2004); In re M.J.M., 858 A.2d 1259, 1267 (Pa. Super. 2004) (citing Commonwealth v. Lutes, 793 A.2d 949, 962 (Pa. Super. 2002)). It is indeed far from clear how pure epithet speech implicates the values or the logic underlying freedom of speech, of a dignitary sort or otherwise, in such a way as to trigger significant free speech protection aside from the step at which dignitary and other costs of epithet speech are taken into account. For recent discussion of Chaplinsky, see Linda Friedlieb, The Epitome of an Insult: A Constitutional Approach to Designated Fighting Words, 72 U. CHI. L. REV. 385 (2005).

225. See supra Part III at text accompanying notes 89-92.

226. See supra text at note 224.

227. See supra note 213. 
rebuttal, or for any dialogue, are nonexistent. The impossibility of any situational "talking back" is clear to all the parties. This effect is presumably intended by epithet hurlers who drive away.

In fact, it would seem that many of the circumstances under which epithets are expressed do not realistically allow any meaningful response in context. Other than the "drive-by" variety, there may be, for example, anonymous notes attached to one's door or one's vehicle, or graffiti in public or private spaces. ${ }^{228}$ None of these media and contexts generally permit direct personal response.

Thus in many of the common hate speech contexts, the idea of stigmatizing the targets as passive and inexpressive, and thus in some sense as lacking in dignity, simply has no basis in the circumstances. ${ }^{229}$ The dignity of the target of hate speech is in even this sense fully implicated. In contrast, whether campus hate speech regulations might create racist martyrs ${ }^{230}$ of any penalized hate speaker may depend on whether a penalty is itself seen as humiliating and undignified or as instead manifesting appropriate respect for the dignity of both the speaker's target and the speaker. ${ }^{231}$

Treating the symptoms of prejudice rather than underlying attitudes, ${ }^{232}$ at least in the context of speech regulation, may also reflect respect for the underlying dignity of both speaker and target. The underlying prejudiced attitudes may be addressed more effectively and with greater respect for dignity by means that supplement, rather than substitute for, appropriate speech regulation. ${ }^{233}$ In the meantime, hate speech targets and neutral observers may value any respite from verbal assaults on the targets' dignity, even if this respite is a matter of merely unprejudiced behavior rather than of unprejudiced underlying attitudes as well. ${ }^{234}$ In

228. See id.

229. It seems undeniable that targets of hate speech can and do offer various sorts of responses to hate speech more indirectly. See id.

230. See supra text at note 224 .

231. In the context of generally Kantian approaches to punishment, see Paul Campos, The Paradox of Punishment, 1992 WIS. L. REV. 1931, 1937, stating that "[f]or Kant, punishing the criminal [in an appropriate way] accords him the respect due a rational being."

232. See supra text at note 224.

233. See Gordon W. Allport, The Nature of PreJudice 472 (1958) (discussing the importance of socialization in the home and in schools).

234. It has been observed that "attitudes do not necessarily translate into behaviors." Chad Trulson \& James W. Marquart, The Caged Melting Pot: Toward an Understanding of the Consequences of Desegregation in Prison, 36 LAW \& SoC'Y REV. 743, 748 (2002). 
fact, such targets may find symbolic value in the official repudiation of hate speech, even if no speakers are sanctioned and no actual reduction in hate speech occurs. ${ }^{235}$

Part of the problem also lies in the focus of some hate speech regulation critics on broad conceptual categories such as offense, possible offense, hurt feelings, or resentment. ${ }^{236}$ These broad categories conceal important differences in intent and effect on dignity. It is common to react with feelings of offense and resentment if one is challenged by any sort of insulting language. Few persons would appreciate being referred to as "snakes," "bedbugs," or "slimy scum.,"237 Even mild epithets, in the context of a political speech or not, and whether addressed to one's supporters or not, can be superficial assaults on the dignity of those to whom the epithets refer. ${ }^{238}$

But such mild epithets generally have no wider and no deeper resonance. In contrast, invidious racial and related epithets, deployed hostilely and often without any pretense to an explicit argument, can instantly evoke historical traditions of lawless violence, intimidation, and brutalization. ${ }^{239}$ To refer to someone as a "snake" is clearly metaphor, and at least faintly ludicrous. No recognizable cultural tradition is evoked by any such reference. No emotively charged history is thereby conjured up. No speaker genuinely expects to intimidate anyone by such language. To thus fail to distinguish among instances of the broad category of offensive or "nasty"240 language in their intent and in their effects on dignity is neither governmental modesty ${ }^{241}$ nor a sensible avoidance of slippery slopes and borderline cases. ${ }^{242}$

235. For discussion of the importance of various sorts of symbolism in politics, see, for example, MURRAy EdElman, THE SyMBolic USES OF Politics (1985).

236. See, e.g., R.A.V. v. City of St. Paul, 505 U.S. 377, 414 (1992) (White, J., concurring); Saxe v. State College Area Sch. Dist., 240 F.3d 200, 215 (3d Cir. 2001) (noting that even some speech widely perceived as offensive or even as gravely offensive may not be proscribed (citing Doe v. Univ. of Mich., 721 F. Supp. 852, 863 (E.D. Mich. 1989) (university hate speech code))); Bair v. Shippensburg Univ., 280 F. Supp. 2d 357 (M.D. Pa. 2003) (university speech code).

237. Terminiello v. Chicago, 337 U.S. 1, 26 (1949) (Jackson, J., dissenting).

238. See id. at 17,21. Speech may be offensive, even at some personal level, without amounting to as clear an assault on the dignity of the offended persons. Consider the circumstances of the public flag burning case of Texas v. Johnson, 491 U.S. 397 (1989).

239. See Virginia v. Black, 538 U.S. 343, 388-91 (2003) (Thomas, J., dissenting) (citing, e.g., WYN C. WADE, THE FIERY CROSS: THE KU KLUX KLAN IN AMERICA 262-63 (1987); JuAn Williams, Eyes on the Prize: AmeriCa's Civil Rights Years, 19541965, at 39 (1987)); RICHARD KLUGER, SIMPLE JUSTICE 378 (1975).

240. See Nicholas Wolfson, Free Speech Theory and Hateful Words, 60 U. CIN. L. REV. 1, 11-12 (1991) (emphasizing the importance of avoiding any pretense of official infallibility).

241. See id.

242. See, e.g., Eugene Volokh, Thinking Ahead About Freedom of Speech and Hostile Work Environment Harassment, 17 BERKELEY J. EMP. \& LABOR L. 305, 313 (1996). 
There is some risk that hate speech regulations may be used against, and not always for, individual members of the most historically oppressed groups. ${ }^{243}$ As well, the dignitary effects of hate speech may not be the same on all targets, largely because history and cultural tradition have not treated all possible target groups equally. Some historically conditioned aspects of dignity may thus suggest somewhat different hate speech rules for different groups. These are complications, however, rather than balance-shifting considerations. In the end, considerations of formal equality under law, ${ }^{244}$ sheer political practicality, and the most stringent demands of Kantian respect for the dignity of persons ${ }^{245}$ would all pull strongly in favor of formally uniform hate speech rules for all groups.

\section{Speech, Equality, and the Mediating Value of Dignity in the Public School Confederate Flag Cases}

Since the classic Tinker $v$. Des Moines Vietnam War protest case decided in $1969,{ }^{246}$ students of various ages have enjoyed free speech rights in the public schools, limited on grounds such as predictable disruption or interference with appropriate school discipline and functioning or with the rights of others. ${ }^{247}$ These speech rights have been further limited in cases in which the speech might reasonably be thought of as specifically approved of by the school itself. ${ }^{248}$ But the possibility of principled conflict between student speech and other important values, such as general equality and civil rights protections, equal educational rights, and sheer social civility, is certainly clear. ${ }^{249}$

Litigation involving such potential conflicts often arises with special sharpness and import in the context of the display in public schools of

243. See, e.g., Strossen, In the Defense of Freedom and Equality: The American Civil Liberties Union Past, Present, and Future, supra note 222, at 151.

244. See, for example, the formal egalitarian absolutism of Justice Stewart concurring in Loving v. Virginia, 388 U.S. 1, 13 (1967), stating "it is simply not possible for a state law to be valid under our Constitution which makes the criminality of an act depend upon the race of the actor."

245. See supra Part III at text accompanying notes 89-92.

246. Tinker v. Des Moines Ind. Comm. Sch. Dist., 393 U.S. 503 (1969).

247. See id. at 514.

248. See Hazelwood Sch. Dist. v. Kuhlmeier, 484 U.S. 260, $270-73$ (1988); Bethel Sch. Dist. No. 403 v. Fraser, 478 U.S. 675, 683 (1986). On the unclear scope of Fraser's limitations of Tinker, see, for example, Denno v. School Board, 218 F.3d 1267, 1274 n.5 (11th Cir. 2000).

249. See, e.g., Saxe v. State College Area Sch. Dist., 240 F.3d 200 (3d Cir. 2001) (broad public school speech code case). 
some version of the Confederate flag. ${ }^{250}$ Such cases are, however, often decided without much explicit comparison of any conflicting values, but more narrowly on the likelihood of a violent confrontation among students involving a Confederate flag. ${ }^{251}$ The problem, though, is that the realistic likelihood in context of a racial incident may reflect considerations apart from conflicting free speech and equality values. In one recent case, for example, the court considered a student population of 1004, of whom a total of fourteen were African-American. ${ }^{252}$ Remarkably, $75-80 \%$ of the students had worn Confederate flags prior to the ban on such attire. ${ }^{253}$ Under these circumstances, including the sheer proportions and raw numbers, the most defensible allocation of rights may well fail to track the predictably low probability of overt racial incidents attributable to the nearly ubiquitous Confederate Flag clothing in particular. ${ }^{254}$ Would we expect many overt instances of violent racial conflict in a school population dominated by actual wearers of Confederate flags?

If we take the most elemental dignitary considerations directly into account in such cases, we can move past any stalemate between free speech and equal protection, as well as any automatic trumping of either claim by the other. Focusing on dignity as an intermediary value admittedly does not simplify the free speech versus equal protection analysis. To begin with, considerations of dignity, at least in some sense of the term, can sometimes be raised on behalf of the Confederate flag wearer. $^{255}$ Thus in a recent case, the trial court observed that:

\footnotetext{
Plaintiff has a strong sense of his southern heritage. He wore the [Confederate] flag shirts and belt buckle in observance of his roots. Plaintiff's father hails from Texas and other family members claim southem heritage as well. Plaintiff also had relatives who fought on the side of the Confederacy during the Civil War. One of the Plaintiff's existing relatives participates in Civil War reenactments. ${ }^{256}$
}

250. See, e.g., Scott v. Sch. Bd. 324 F.3d 1246 (11th Cir. 2003); Castorina v. Madison County Sch. Bd., 246 F.3d 536 (6th Cir. 2001); Denno, 218 F.3d at 1274; West v. Derby Unified Sch. Dist. No. 260, 206 F.3d 1358 (10th Cir. 2000); Bragg v. Swanson, 371 F. Supp. 2d 814 (W.D. W. Va. 2005).

251. The inquiry into prior racial incidents in, for example, Sypniewski v. Warren Hills Regional Board of Education, 307 F.3d 243 (3d Cir. 2002), is typical in this regard.

252. See Bragg, 371 F. Supp. $2 \mathrm{~d}$ at 816.

253. See id. at 820.

254. See id.

255. We here set aside the possibility that turning oneself into a commercial or even a noncommercial billboard in a public school setting is itself inconsistent with the fullest dignity of the person.

256. Bragg, 371 F. Supp. 2d at 820. 
The plaintiff's wardrobe emphasized depictions of the Confederate flag. ${ }^{257} \mathrm{He}$ apparently wore some Confederate flag image to school nearly every day for three years. ${ }^{258}$ Such a plaintiff can certainly be said to identify with the South, at least in some vague sense. Nor are there unlimited means of publicly conveying to others that particular social identification. Publicly meaningful symbols of one's basic social identifications cannot just be selected arbitrarily and then become immediately effective. ${ }^{259}$

On the other hand, we might ask whether a merely vague pride in or identification with the South could not be conveyed as clearly and as meaningfully by slogans, graphics, maps, or logos not involving the Confederate flag. The Confederacy, after all, occupies only four of the South's hundreds of years of distinctive history and culture. Is the focus on the Confederacy intended instead to suggest a special devotion to the South as it was one hundred and fifty years ago, as distinct from the most recent fifty or one hundred years? Why such a specialized attraction? Is the Civil War as opposed to Southern history generally a point of special pride and identification? Why? What would be the public justification?

In the reported cases, the avowed intentions underlying a Confederate flag's focus seem to vary significantly. Some of the expressed attitudes may strike some as harmlessly disproportionate. ${ }^{260}$ Some students may even admit their ignorance of any message likely to be conveyed by the Confederate flag. ${ }^{261}$ Other students who emphasize Confederate flag regalia essentially drop any pretense that their message of identification is entirely non-racist in nature. ${ }^{262}$

257. See id. at 819 .

258. See id.

259. Hence the controversy over the French ban in public schools of "conspicuous" as opposed to "discreet" religious symbols such as Muslim head scarves, large Christian crosses, and Jewish skullcaps. See, e.g., Elaine Sciolino, Chirac Backs Law to Keep Signs of Faith Out of School, N.Y. TIMES, Dec. 18, 2003, at A17.

260. See Bragg, 371 F. Supp. 2 d at 819.

261. One disciplined middle school student provided the following account:

I was sitting in math class and I had a piece of paper that I was going to make a plane on and Dusty Houston told me to write a rebel flag on it and I said no and he asked me if I even knew what it was and I said yes but I didn't know what it meant. So I drew it and he turned me in.

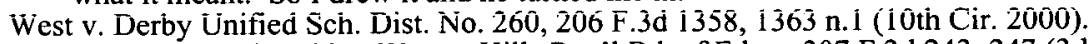

262. See Sypniewski v. Warren Hills Reg'1 Bd. of Educ., 307 F.3d 243, 247 (3d Cir. 2002) ("Some [students] formed a 'gang-like' group known as 'the Hicks' and observed 'White Power Wednesdays' by wearing Confederate flag clothing."). 
Yet other Confederate flag-wearing public school students assert their lack of any invidious racial intention. ${ }^{263}$ For some, the Confederate flag is a "proclamation of heritage" 264 or "a non-racist memorial to their Southern heritage." 265 It is also said, however, that "the vast majority ... understand that one['s] ... proclamation of heritage is another's reminder of the unspeakable cruelties of human bondage."266 For some persons, despite any professed innocence or neutrality of intent, ${ }^{267}$ the Confederate flag unavoidably evokes a historic cultural nightmare ${ }^{268}$ For such persons, the display of the Confederate flag becomes a "term or condition" of public school attendance on a basis unequal with those of Caucasian students.

A public school may thus be forced to choose between protecting the free speech rights of some students to wear clothes displaying the Confederate flag, and protecting the statutory or constitutional equal protection rights of other students who wish an educational opportunity as free of significant distractions as that available to other students. So conceived, the tradeoff is centrally between the free speech rights of some and the equal protection rights of others.

It is a tempting mistake to focus on the role of dignity, civility, or respect in the public schools, and then to set off such dignitary values themselves directly against freedom of speech. To one degree or another, the case law provides for the pursuit of civility, shared values, non-offense, and mutual respect, at some cost to otherwise protected speech in public schools. ${ }^{269}$ But to set freedom of speech directly

263. See, e.g., Denno v. Sch. Bd., 218 F.3d 1267, 1274 n.6 (11 th Cir. 2000).

264. Bragg, 371 F. Supp. 2d at 816 (quoting Sons of Confederate Veterans, Inc. v. Comm'r, 305 F.3d 241, 242 (4th Cir. 2002) (Wilkinson, C.J., concurring in denial of rehearing en banc)).

265. Denno, 218 F.3d at 1274 n.6.

266. Bragg, 371 F. Supp. 2d at 816 (quoting Sons of Confederate Veterans, 305 F.3d at 242).

267. See Denno, 218 F.3d at 1274 n.6.

268. See id.; Scott v. Sch. Bd., 324 F.3d 1246, 1248-49 (11 th Cir. 2003).

269. See Bethel Sch. Dist. No. 403 v. Fraser, 478 U.S. 675, 683 (1986); see also Denno, 218 F.3d at 1271. A key uncertainty as to the scope of Fraser is whether the school's civility-inculcation function is limited to curricular and distinctly schoolsponsored functions, or whether the school's civility-inculcation function may justify restriction of student speech in other contexts as well. See, e.g., Fraser, 478 U.S. at 681 (focusing on a school assembly program); Newsom v. Albemarle County Sch. Bd., 354 F.3d 249, 256 (4th Cir. 2003) (interpreting Fraser limitations on "plainly offensive" speech as addressing the form or manner but not the "content" of the regulated speech); Muller v. Jefferson Lighthouse Sch., 98 F.3d 1530, 1537-38 (7th Cir. 1996) (student speech in a nonpublic forum as governed by the lax Hazelwood rational basis test even if the speech was not clearly school sponsored); Chandler v. McMinnville Sch. Dist., 978 F.2d 524, 529 (9th Cir. 1992) (detecting three categories: "vulgar, lewd, obscene, and plainly offensive speech, ... school-sponsored speech, and ... speech that falls into neither of these categories") (first category may be restricted even outside context of the 
against the net balance of the arguably mixed or conflicting ${ }^{270}$ dignitary effects noted above ${ }^{271}$ in the Confederate flag context is to compare a recognized constitutional right with merely a balance of dignitary considerations, none of which by itself rises to the level of a constitutional right.

We might rightly assume that the indignity of recurrent reminders, intended or not, of historic barbarities outweighs the indignity of merely selecting another way of conveying authentic regional pride through school clothing. Nonetheless, we cannot balance a constitutional right to speech with dignity considerations, however morally basic, and however linkable to constitutional rights, that do not themselves amount to a constitutional right. ${ }^{272}$

Instead, the proper role of dignitary considerations is to mediate between the free speech and equal protection implications of the Confederate flag cases. While both free speech and equal protection claims raise direct issues of constitutional right, and dignity in even the most crucial sense does not, dignitary considerations can be used to translate and more persuasively adjudicate the conflicts between free speech and equal protection.

We may rightly conclude that in the typical public school Confederate flag case the balance of the deepest, most serious, and least merely

second category); Griggs v. Fort Wayne Sch. Bd., 359 F. Supp. 2d 731, 740-41 (N.D. Ind. 2005) (discussing Muller); Harper v. Poway Unified Sch. Dist., 345 F. Supp. 2d 1096,1103 (S.D. Cal. 2004) (similarly applying Chandler to scope of Fraser); Pinard v. Clatskanie Sch. Dist., 319 F. Supp. 2d 1214, 1217 (D. Or. 2004) (same).

270 . This is not to suggest that the dignitary effects in Confederate flag cases are equal or that they operate at the same level and partake of the same sense of dignity. It should not be difficult to determine that the dignitary value of being spared graphic reminders of brutal historical depredations will typically outweigh the loss of dignitary value between wearing a Confederate flag to school and wearing some other representation of regional pride.

271. See supra notes $253-57,261-64$, and accompanying text. The balancing of dignitary interests should not provide incentives for exaggerated claims, hysterical overreactions, hypersensitivity, or largely "strategic" outrage, in an attempt to outweigh the other side. But some forms of dignity and indignity are, by a consensus elsewhere fairly established, more basic than others and obviously grounded in the events of American cultural history.

272. Attempts to protect dignity generally or to promote mutual respect generally in public schools are likely to be seen to trench upon free speech rights. See, e.g., Saxe v. State College Area Sch. Dist., 240 F.3d 200, 217 n.12 (3d Cir. 2001) (discussed in Sypniewski v. Warren Hillis Reg'I Bd. of Educ., $307 \mathrm{~F} .3 \mathrm{~d} 24 \overline{3}, 26 \mathrm{i})$. But cf. Borof v. Van Wert City Bd. of Educ., 220 F.3d 465, 470 (6th Cir. 2000) (upholding regulation of non-racially offensive lyrics where the school policy had emphasized, inter alia, "human dignity and worth" rather than focusing especially on equality). 
adolescent dignitary claims, given the alternative available means of speaking, lies typically in favor of the equal protection claims at some limited expense to freedom of student speech. Dignitary considerations in this kind of case will thus ordinarily tip in favor of the equality claims.

But can such an approach and general conclusion be accused of hypocrisy? What if some African-American students wore " $\mathrm{X}$ " clothes to public school, ${ }^{273}$ with whatever intent, and some Caucasian students interpreted the symbolic speech as supporting not only Malcolm X and the Black Muslim movement, but hostility toward Caucasians in general? How, consistent with the above analysis of the Confederate flag cases, should such a case be approached?

Such a case would set the specific free speech rights of the AfricanAmerican students against whatever equal protection claims the Caucasian students could cogently make. Various dignitary considerations would arise on both sides. Among most obvious points, the nature and weight of interests of African-Americans and Caucasians are not always symmetrical as a matter of history and culture. Patterns of legal dominance, subordination, and control are not casually reversible or subject to dismissal on the basis of some formal symmetry. The stigma and cultural baggage associated with arguable hate speech is not always the same in either direction. Historical dominance and subordination do not leave essentially similar impacts on the involved groups. This is largely a matter of taking the inequalities, and the subordination, seriously.

We would have no reason to imagine that the psychological and related dignitary effects of wearing " $X$ " clothing in a public high school in Eastern Kentucky ${ }^{274}$ would parallel those of wearing a Confederate flag under otherwise similar circumstances. We could not expect epithets targeted at Caucasians to have the depth of dignitary effects comparable to Klan-oriented epithet speech, ${ }^{275}$ given our cultural history. The asymmetric power relationships involved, the events of history, and the continuing disparities in power and influence, make it more likely that no epithet can target Caucasians with comparable effect.

For the sake of encouraging reasonable regulation and other dimensions of practical political realism, we could well make the strategic calculation that all legal restrictions on group-offensive clothing should be formally neutral. No group would be allowed to speak through

273. See Castorina v. Madison County Sch. Bd., 246 F.3d 536, 541 (6th Cir. 2001).

274. See id.

275. See, e.g., Church of the Am. Knights of the Ku Klux Klan v. City of Gary, 334 F.3d 676, 684 (7th Cir. 2003). 
images understandably offensive to any other cognizable group. Such rules may be in practice more broadly politically acceptable, whatever their cultural and historical or psychological realism, or their potential for abuse.

\section{CONCLUSION}

The above explorations of some forms of hate speech, and of Confederate flag display in the public schools, are only illustrations. They show, however, that basic understandings of dignity, along generally Kantian lines, can be used to do extremely important adjudicative work. Without itself rising to the level of a constitutional right, the idea of dignity can, with logic and legitimacy, be employed to choose between unavoidably conflicting values of free speech and equal protection.

The idea of dignity will not always point unequivocally to a single constitutional outcome. But conflicts between free speech and equal protection, as well as between free speech and other constitutional values, are so frequent, so important, and so otherwise intractable that we should further explore any promising means of resolving them. 
